\title{
Monetary Policy and Bank Profitability in a Low Interest Rate Environment*
}

\author{
Carlo Altavilla \\ European Central Bank
}

Miguel Boucinha

European Central Bank
José-Luis Peydró

ICREA-UPF, CREI, BGSE

\begin{abstract}
We analyse the impact of standard and non-standard monetary policy on bank profitability. We use both proprietary and commercial data on individual euro area bank balance-sheets and market prices. Our results show that a monetary policy easing - a decrease in short-term interest rates and/or a flattening of the yield curve - is not associated with lower bank profits once we control for the endogeneity of the policy measures to expected macroeconomic and financial conditions. Accommodative monetary conditions asymmetrically affect the main components of bank profitability, with a positive impact on loan loss provisions and non-interest income offsetting the negative one on net interest income. A protracted period of low monetary rates has a negative effect on profits that, however, only materialises after a long time period and is counterbalanced by improved macroeconomic conditions. Monetary policy easing surprises during the low interest rate period improve bank stock prices and CDS.
\end{abstract}

JEL: E52, E43, G01, G21, G28.

Keywords: bank profitability, monetary policy, lower bound, quantitative easing, negative rates.

\footnotetext{
* This draft is from 2018. We would like to thank Puriya Abbassi, Nuno Alves, Miguel Ampudia, Philippe Andrade, António Antunes, Diana Bonfim, Sarah Holton, Yann Koby, Benoit Mojon, Peter Praet, Elena Rancoita, Massimo Rostagno, Enrico Sette, Frank Smets, Andrea Tiseno, Skander Van den Heuvel and seminar participants at the ECB, National Bank of Belgium, Banque de France, Oesterreichische Nationalbank, Universitat Pompeu Fabra, and Bank of Portugal, for their helpful comments and suggestions. The opinions in this paper are those of the authors and do not necessarily reflect the views of the European Central Bank or the Eurosystem. José-Luis Peydró acknowledges financial support from the Spanish Ministry of Economy, Industry and Competitiveness, Grant ECO2015-68136-P and FEDER, UE, and from the European Research Council Grant (project 648398). Please address any comments to Carlo Altavilla: carlo.altavilla@ecb.europa.eu; Miguel Boucinha: Miguel.Boucinha@ecb.europa.eu; or José-Luis Peydró: jose.peydro@upf.edu.
} 


\section{Introduction}

The accommodative monetary policy cycle that followed the financial crisis in many countries has led to an intense debate on the potential side effects for the banking system of a (very) low interest rate environment, especially when protracted for an extended period of time. Understanding the potential adverse impact of these measures on bank profitability has crucial policy implications. Low profitability affects banks' ability to generate capital internally through retained earnings, thereby potentially hampering bank ability to provide sufficient credit to the economy. This would affect banks' resilience to adverse shocks possibly leading to costs for bondholders, depositors and ultimately tax payers (Admati and Helwig, 2013; Freixas and Rochet, 2008). ${ }^{1}$ Therefore, bank profitability contributes to bank soundness and to financial stability.

Conventional and unconventional monetary policies have nonetheless played a crucial role in addressing weak macroeconomic performance and supporting financial intermediaries (Freixas, Laeven and Peydró, 2015). This is because such measures provide abundant access to central bank liquidity and lower the cost of debt with positive consequences for bank funding and borrower creditworthiness respectively, thereby supporting bank capital and reducing non-performing loans and loan loss provisioning (Bernanke and Gertler, 1995; Diamond and Rajan, 2006; Freixas and Jorge, 2008; Gertler and Karadi, 2011, 2013; Kiyotaki and Moore, 2012; Freixas, Martin and Skeie, 2011; Allen, Carletti and Gale, 2009 and 2014; Praet, 2016). However, there may also be downsides associated with monetary policy easing (Rajan, 2005; Allen and Rogoff, 2011; Stein, 2012 and 2014; Stiglitz, 2016), in particular when interest rates remain too-low-for-too-long (Taylor, 2008; Maddaloni and Peydró, 2011). These potential downsides include a reduction in net interest income (Borio et al., 2017; Alessandri and Nelson, 2015) which could ultimately hamper the transmission of monetary policy (Brunnermeier and Koby, 2017). The net effect of monetary policy on bank profitability therefore remains an empirical question, including whether a scenario of low (or even negative) rates protracted for an extended period of time alters the relationship between monetary policy easing and bank profitability.

In this paper, we analyse the impact of conventional and unconventional monetary policy on bank profitability. We focus on the euro area, which features substantial bank and country heterogeneity within a monetary union where the central bank has implemented a broad set of unconventional monetary policies, including negative (nominal) interest rates, credit and quantitative easing

\footnotetext{
${ }^{1}$ Although an assessment of the optimal level of bank profits is outside the scope of the present paper, we argue that a banking system where financial intermediaries suffer from structurally lower profits is more exposed to adverse shocks. However, it is not clear whether a higher level of profitability is always desirable. As an example, if higher profits are driven by excessive risk-taking, they may negatively affect the market perception of risk, the bank's funding costs, and thereby banks' overall value.
} 
measures. At the same time, bank profitability in the euro area has remained at relatively low levels (compared to USA, see next section). We use proprietary European Central Bank (ECB) data on individual bank balance sheets, in conjunction with data from several commercial providers collected since the creation of the euro area, including financial market prices.

We analyse the average impact of monetary policy on bank profits as well as its heterogeneous effects across the main different profit components. In particular, we explore the main channels though which monetary policy actions influence bank profitability. At a micro-econometric level, we use bank-level data to analyse the impact of monetary interest rate changes on the main components of bank profitability - i.e. net interest income, non-interest income and provisions. We complement this micro evidence by investigating the macroeconomic implications of changes in monetary conditions on the same components using a dynamic multivariate macro-econometric model that incorporates feedback effects from monetary policy to GDP growth, and hence to bank conditions. We also analyse heterogeneous effects depending on banks' maturity transformation, and balance sheet strength. Moreover, as there have been growing concerns over recent years that the net benefits of accommodative policies might be declining over time (Brunnermeier and Koby, 2017; Claessens, 2017), we examine whether a protracted period of low interest rates might impair bank profitability. ${ }^{2}$

As bank profits are crucial for bank capital (and hence for financial stability and bank soundness), we also assess the impact of non-standard monetary policies on stock market returns of individual banks, which provides evidence on market-based expectations of future profitability. Since bank shareholders could pursue strategies of excessive risk-taking to maximize bank profits and the vast majority of the stakeholders of a bank are debtholders, we also investigate the impact of monetary policy measures on market participants' perception of banks' credit risk, as proxied by banks' CDS spreads, thereby covering the impact for all the major stakeholders of a bank, ultimately including depositors and taxpayers. ${ }^{3}$ We use an event-study approach to isolate the unexpected component of the policy change by analysing high-frequency movements in asset prices following monetary policy announcements. ${ }^{4}$

\footnotetext{
2 As shown in theoretical studies (see e.g. Brunnermeier and Koby (2017) and Bernanke and Gertler (1995), among others), monetary policy affects banks via their maturity transformation from bank liabilities to bank assets - hence banks with different maturity mismatch are differently affected - and via bank balance sheet strength - hence banks with different balance sheet strength are differently affected. At the same time, policy institutions have also dedicated considerable attention to the potential side effects of protracted period of low interest rates. See for example the ESRB document on "Financial Risks in a Low Interest Rate Environment" as well as the chapter of the 2017 IMF Global Financial Stability report.

${ }^{3}$ Note that the analysis of bank strategies to pursue excessive risk-taking, including gambling for resurrection and zombie lending (see e.g. Caballero et al. 2008; Iyer et al. 2014), is beyond the scope of this paper (and our current data). Adequate identification would require a European credit register dataset.

${ }^{4}$ See, for example, Bernanke and Kuttner, 2005; Gürkaynak, Sack and Swanson, 2005b. The identifying assumption is that changes in asset prices occurring in a small window around a given policy announcement
} 
This paper mainly contributes to the literature on the impact of monetary policy actions on bank profitability. Early studies document the existence of a positive correlation between interest rates (usually expressed as level or slope of the term structure) and bank interest margins. This positive association is interpreted as a natural consequence of banks' maturity transformation activities (e.g. Flannery, 1981; Hancock, 1985; Bourke, 1989; Saunders and Schumacher, 2000). Recent studies have also highlighted the possible trade-off between accommodative monetary policy and bank profitability. In general, the empirical evidence found in these studies suggests an adverse impact of monetary policy easing on net interest margins and profits (Alessandri and Nelson, 2015), with amplification effects in low and protracted interest rate environments (Borio et al., 2017; Claessens et al., 2017).

Regarding our main contribution, we establish a set of robust results, using a wide range of different data and econometric techniques.

First, we find that, when evaluating the impact of monetary policy on bank profitability, it is crucial to consider the effects stemming from not only actual but also expected real economic activity. We are, to our knowledge, the first in the above literature to use the expected (forecasted) macroeconomic developments and (forward-looking) credit risk among the possible set of controls, which are crucial variables for central bankers to set their monetary policies. We find that lower monetary policy rates and a flattening of the yield curve are associated with lower bank profits only if there are important variables omitted in the assessment. More specifically, according to economic theory and central bank practice (see, for example, Bernanke and Gertler, 1995), monetary policy reacts (is endogenous) to the current and expected overall economic and financial conditions. If we control for these factors, the association between monetary policy and bank profitability breaks down. Bank balance sheet characteristics, such as bank capital, liquidity, non-performing loans and efficiency, are also important. This is not surprising, as weakness in bank balance sheets (and the associated impairment in the transmission mechanism) was an important motivation for monetary policy easing during the crisis (Praet, 2016). ${ }^{5}$

Second, the main components of bank profitability are asymmetrically affected by accommodative monetary policies with a positive impact on loan loss provisions and non-interest income, offsetting

capture the (efficient) market reaction to the arrival of new information, thereby reflecting the causal impact of monetary policy. Note that the dynamics of both bank stock prices and CDS are affected by a wide range of factors, making it challenging to identify the effects of monetary policy, and by being forward-looking, financial market prices tend to react to information about policy changes only if these changes are unanticipated. Hence, for asset prices is necessary the high frequency analysis around policy announcements.

${ }^{5}$ There is a large literature on the monetary policy transmission mechanism that explores the impact of monetary policy, and in general central bank policies, on the economy via banks (Bernanke and Blinder, 1988 and 1992; Kaskyap and Stein, 2000; Diamond and Rajan, 2006; Gertler and Kiyotaki, 2010; Jiménez, Ongena, Peydró and Saurina, 2012, 2014, and 2017). 
a negative one on net interest income, a robust result stemming from our both micro and macro approaches. ${ }^{6}$

Third, we find that heterogeneity of bank balance sheet characteristics matters for the transmission of monetary policy to bank profitability. Results suggest that an accommodative monetary policy is relatively more beneficial for banks with higher operational efficiency and banks with lower asset quality. Additionally, a steepening of the yield curve has a relatively more positive impact on profitability for banks that rely more heavily on maturity transformation activities (see also English et al., 2014). ${ }^{7}$

Fourth, while monetary policy easing does not compress bank profits, we find that being exposed to a low interest rate environment for a protracted period might exert downward pressure on bank profitability. However, results from our dynamic macro model show that the positive impact of monetary policy easing on real economic activity (and hence on banks) counterbalances the negative effects of low interest rates on net interest income. ${ }^{8}$

The paper also contributes to the literature on the impact of monetary policy on expected profitability of firms as measured by stock market returns (Thorbecke, 1997; Bernanke and Kuttner, 2005; Rigobon and Sack, 2004; Ehrmann and Fratzscher, 2004; English, et al., 2014). In this context, we also highlight the importance of considering the effects of monetary policy actions on both debtholders' net wealth and credit risk; this is not only important for financial stability and systemic risk but also economically relevant as bank debt, including depositors, accounts for the vast majority of banks' value, and bank profits could be higher due to risk-shifting strategies, or could be manipulated by zombie lending strategies (Freixas, Laeven and Peydró, 2015).

Regarding our second contribution, evidence from financial markets provides striking results. After all major monetary policy easing announcements (including long-term liquidity provision, quantitative easing and negative policy rates) during the period of very low monetary policy rates, the vast majority of banks experience an increase in the market-based expected profitability proxied by developments in bank stock prices - and a decrease in market perception of bank credit risk - proxied by bank CDS spreads. These two results also imply that looser monetary conditions

\footnotetext{
${ }^{6}$ Our macro results show that, following an easing monetary shock, real GDP, lending volumes and inflation increase, thus reflecting improved economic prospects associated with better financial conditions. The degree of accommodation is also passed-through to borrowing conditions, thereby compressing lending rates. Moreover, changes in economic activity and monetary policy are also transmitted to bank profitability and its components. The reduction in interest rates on a large set of financial assets at different maturities is reflected in lower bank net interest income; however, non-interest income is increased and provisions are reduced.

${ }^{7}$ Note that the maturity mismatch between bank assets and liabilities is difficult to measure. For example, there are asset classes such as overdrafts that although short-term, do not have a specific maturity.

${ }^{8}$ The finding that the potential negative impact of monetary accommodations on bank profitability is partially offset by the improving macroeconomic conditions is based on the following findings. The results of the micro econometric model show a positive estimated coefficient of expected real GDP growth on bank profits, while the macro dynamic econometric model (that incorporates feedback effects) shows that loose monetary conditions affect positively future GDP growth (and hence bank profits).
} 
do not hurt banks' main stakeholders (including debtholders and in general depositors and taxpayers)..$^{9}$ Overall, the evidence from financial markets supports the conclusions drawn from the analysis of bank balance sheets, namely that monetary policy easing does not impair bank profitability (nor overall bank value), though our paper is silent on medium- and long-term distortionary effects. ${ }^{10}$

The remainder of the paper is organised as follows. Section 2 presents stylised facts on recent developments in bank balance sheet structure and profitability. In Section 3, the analysis focuses on the impact of monetary policy on bank profitability using accounting data for a cross-section of European banks. Section 4 complements the evidence based on bank-level data by investigating the macroeconomic implications of monetary policy shocks on profitability components using a dynamic multivariate macro model. Section 5 extends the assessment to the impact of monetary policy on banks' market valuations and credit risk as determined by financial market participants. Section 6 concludes.

\section{Stylised facts}

As suggested in the introduction, an adequate level of profit is essential for the financial intermediaries to be able to generate capital internally as well as to originate sufficient credit to the private sector. This of course does not mean that the efficiency of the banking sector to allocate credit increases linearly with the profits as the optimal level of banks' profitability is likely to depend on many concurrent factors and also to vary over the business cycle. However, a banking system with a structurally lower level of profitability with respect to another is certainly less able to face and overcome unexpected adverse shocks. Figure 1 illustrates that, indeed, there is a persistent difference in the level of bank profitability (as measured by the return on assets) between European and US banks. This difference dates back to at least the early 2000s and would suggest that although improving towards the end of the sample period, low profitability continued to be a major challenge for the euro area banking sector.

\footnotetext{
${ }^{9}$ Bank value is composed of the value of bank shares plus the value of bank debt. As discussed in the main text, given that banks are highly leveraged, even more so in Europe than the United States, most of the bank value stems from bank debt.

${ }^{10}$ Although our results show that monetary policy easing does not hamper bank profitability, stock market values and CDS spreads, there could be distortionary effects materialising in the medium- to long-term horizons due to excessive bank risk-taking (Jiménez et al, 2014) and zombie lending/loan ever-greening practices (Freixas, Laeven and Peydró, 2015).
} 
Figure 1: Bank profitability in the Euro Area and the United states

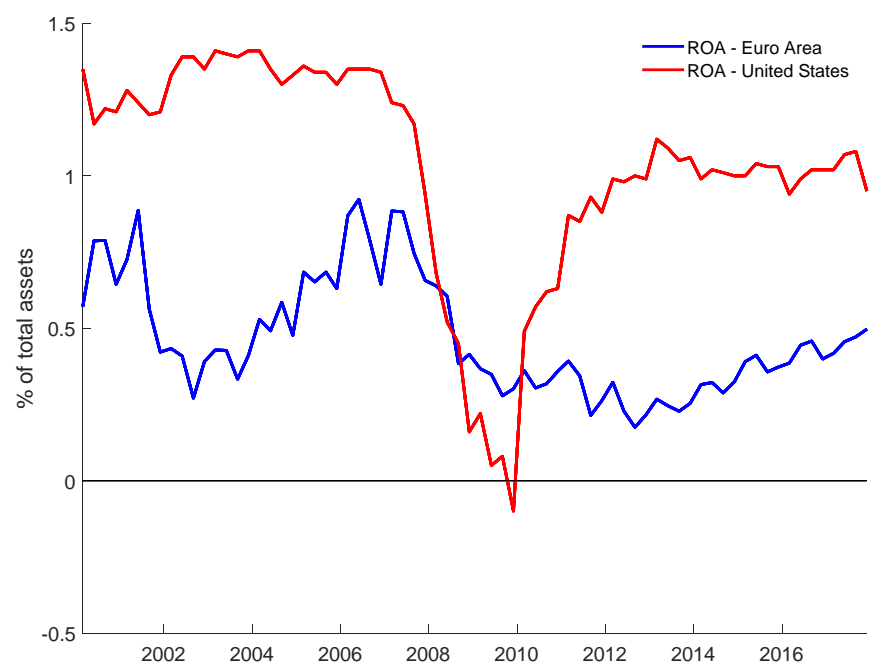

Note: the chart reports the Return on Asset in the Euro Area and the United States. For the US banks, the source is: Federal Financial Institutions Examination Council (US), Return on Average Assets for all U.S. Banks [USROA], retrieved from FRED, Federal Reserve Bank of St. Louis; https://fred.stlouisfed.org/series/USROA. For the euro area banks the source is: Bankscope, SNL, Bloomberg and Capital IQ. Details on the dataset used in the analysis are provided in Section 3.1.

In principle the impact of monetary policy actions on bank profitability might be ambiguous. This ambiguity is related to the fact that the effects on net interest margins driven by relative frictions in pricing assets and liabilities can be offset by general equilibrium effects associated with the reaction of credit quality and intermediation volumes to changes in interest rates. By aiming at compressing risk/term premia by altering the size of the central bank balance sheet, quantitative easing (QE) policies, for example, might produce two contrasting and possibly offsetting effects. On the one hand, the flattening of the yield curve typically associated with this type of policy may reduce the returns from maturity transformation activities and thus compress banks' net interest margins (e.g. Alessandri and Nelson, 2015; Altavilla, Canova and Ciccarelli, 2016). On the other hand, QE may improve bank profitability by boosting demand for credit, as the policy is transmitted to the real economy. The effect of the policy on real economic activity might also improve the capacity of borrowers to honour their commitments, increasing the quality of the assets held in banks' portfolios and hence allowing for savings in costs associated with loan loss provisions.

How exactly bank profitability is affected by interest rate changes depends on the relative effects on its main components: net interest income, non-interest income, and provisions. Figure 2 illustrates the developments over time in bank profitability and its main components as well as their cross-sectional dispersion. Bank profitability showed an increasing trend in the run-up to the financial crisis, followed by a decline reflecting an abrupt increase in loan loss provisions. More recently, there has been a gradual recovery of bank profitability supported by increasing net interest 
income and declining provisions, reflecting higher credit quality thanks to the improved economic outlook. The resilience of net interest income in the recent low interest rate environment reflected savings in funding costs which more than offset lower interest income. In turn, interest income was supported by increasing intermediation volumes.

Figure 2: profitability and its main components
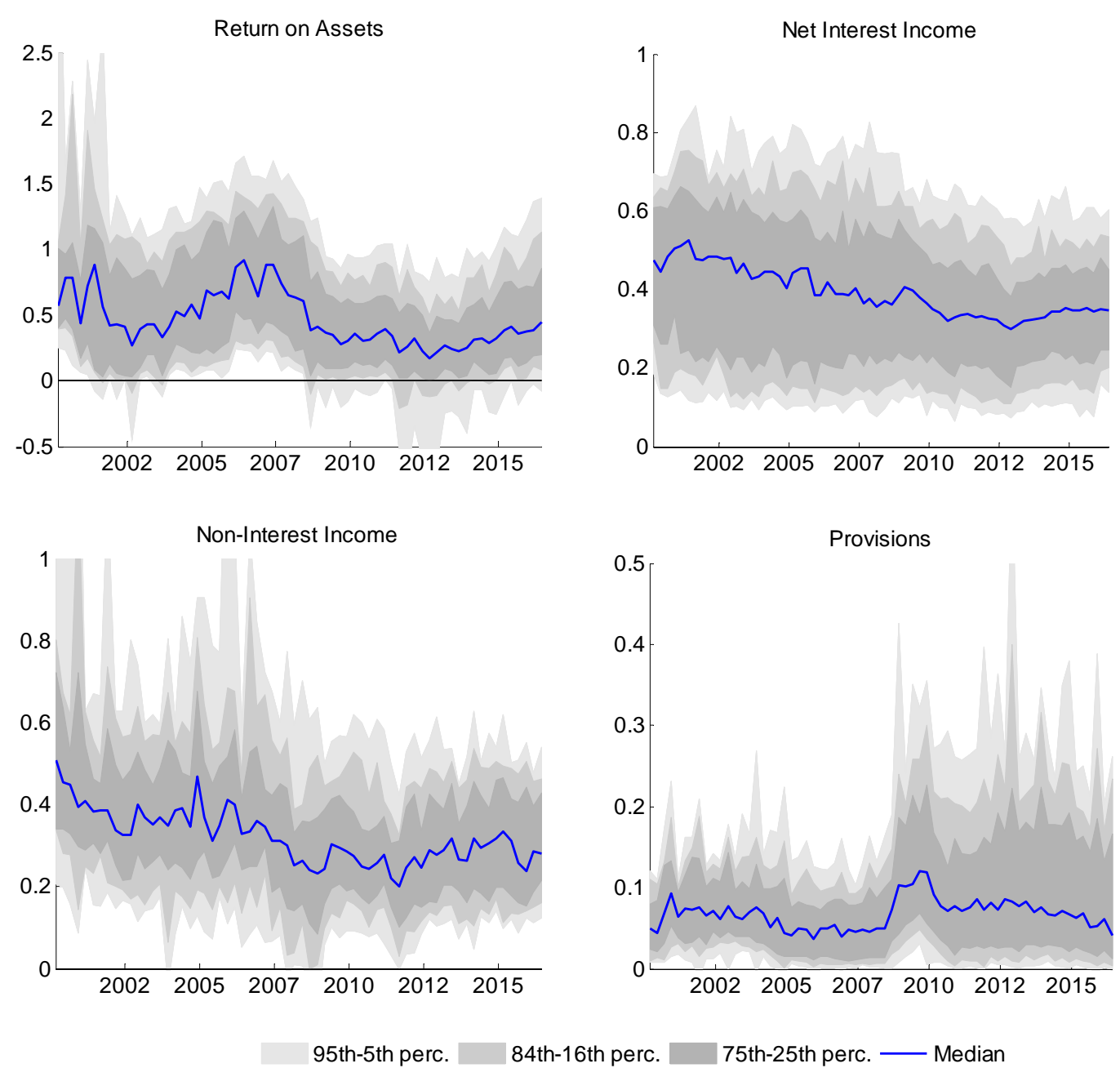

Note: the figure illustrates the developments over time in the main components of bank profitability (as a percentage of total assets - reported on the y-axes) and their cross-sectional dispersion across the available sample of banks. The blue line represents (for each quarter) the median for the cross-section of banks. Similarly, the shaded areas comprise the interquartile range, the $50 \%, 68 \%$ and the $95 \%$ of the cross-sectional distribution of banks. Data are from Bankscope, SNL, Bloomberg and Capital IQ. Details on the dataset used are provided in Section 3.1.

In order to understand the link between monetary policy and interest rates, it is important to have an overview of the main components of bank balance sheets in the euro area. Loans and advances are the main component of total assets. For the euro area as a whole, total loans comprise around $60 \%$ of total assets, whereas loans to the non-financial private sector account for close to $40 \%$. Securities held represent $15-20 \%$ of the balance sheet, and about $2 / 3$ of this item is comprised by sovereign debt, with equity instruments accounting for around $10 \%$ of securities held by euro area 
banks. Among the other assets, the main components are derivatives and cash and balances at central banks. The largest component of the liability side is deposits, at around $60 \%$ of total assets, of which about $60 \%$ are deposits from the non-financial private sector. Securities issued account for around $15 \%$ of total liabilities and capital accounts only for close to $6 \%$. Other liabilities largely comprise derivatives.

The different characteristics of bank assets and liabilities which are relevant for the link between the balance sheet structure and bank profitability can be summarised by the maturity gap. This indicator measures the difference between the (weighted average) repricing period of bank assets and liabilities. ${ }^{11}$ More formally, this indicator might be expressed as:

$$
G A P_{i, j, t}=\sum_{j} \tau^{A, j} A^{j}-\sum_{j} \tau^{L, j} L^{j}
$$

where $\tau^{A, j}$ denotes the weighted average repricing/maturity period (in months) of assets $\left(A^{j}\right)$, which comprise loans to the non-financial private sector, whereas $\tau^{L, j}$ refers to the repricing time of the liabilities $L^{j}$, which in our case include deposits from the non-financial private sector.

Figure 3: Maturity gap distribution across bank

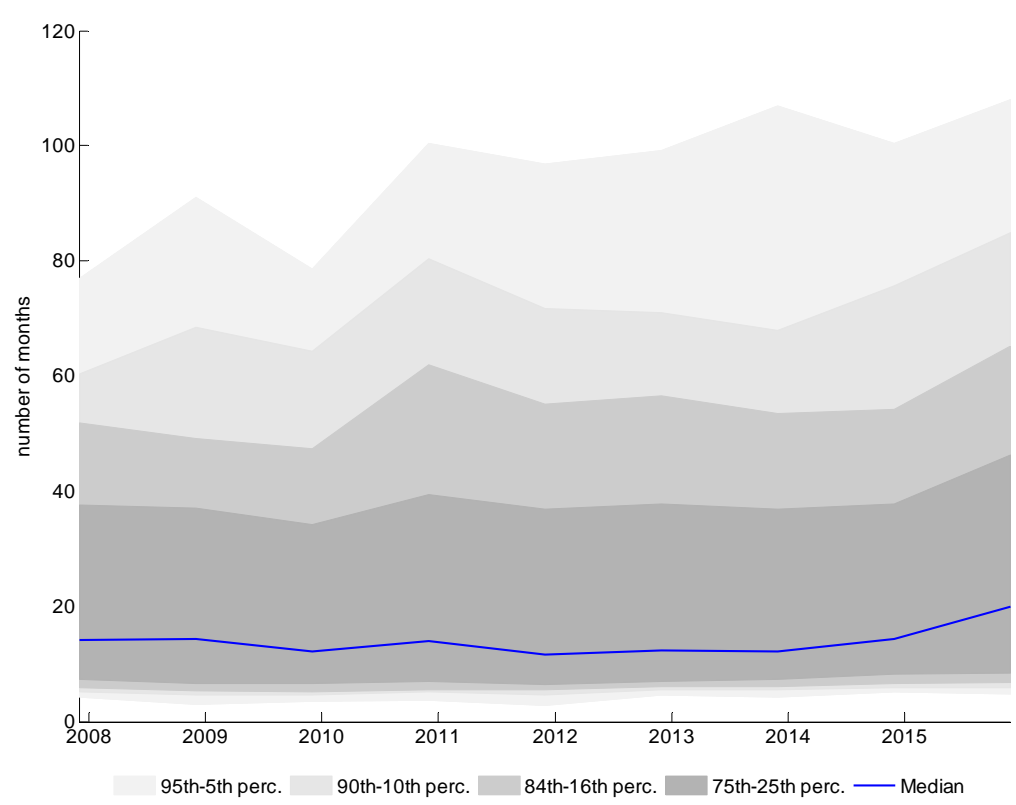

Note: for each month, the chart reports the dispersion of the maturity gap across banks. The maturity gap considers loans to and deposits from the non-financial private sector based on new business volumes for each maturity bucket, relating to new loans plus loans whose rate is renegotiated. Weighted average rate fixation is calculated using the mid-point of each rate fixation bracket and 15 years for the bracket "over 10 years". Data are from the ECB's individual balance sheet items dataset (iBSI). Details on the dataset are provided in Section 3.4.

${ }^{11}$ Note that the maturity gap (see English et al., 2014) is similar to the "funding gap" introduced by Flannery (1983). 
Figure 3 illustrates the significant cross-sectional dispersion in maturity transformation, possibly reflecting different business models as well different loan-rate fixation periods. ${ }^{12}$ The median maturity gap has recently increased to about 2 years, whereas its distribution ranges from 6 months to around 8 years. The link between the maturity gap and the impact of monetary policy on bank profitability is explored in the next section.

\section{Exploiting the cross-section of banks}

In this section, the analysis concentrates on the impact of monetary policy on bank profitability using accounting data for a cross-section of European banks. Return on assets is used as a measure of profitability and regression analysis is employed to explore its drivers. In general, we examine the role of monetary policy, the macroeconomic outlook and bank balance sheet characteristics. In doing so, we rely on different datasets with different degrees of confidentiality/granularity. More specifically, the analysis is carried out at quarterly frequency, matching different commercial datasets available since the establishment of the euro area with different confidential ECB proprietary datasets available at monthly and quarterly frequency over the period from June 2007 to January 2017. Therefore, data availability explains why there may be differences in some empirical specifications used in the analysis below.

\subsection{Monetary policy and bank characteristics}

In this subsection, we explore the link between monetary policy and bank profitability through the lens of bank balance sheet information. We also analyse whether bank characteristics influence the transmission of monetary policy actions to bank profitability. The analysis focuses on the period from the start of 2000 to the end of 2016. We use quarterly data collected from different sources. More specifically, we use three sets of variables. Financial variables, such as the yield curve and the VIX, are taken from Datastream, while the country-specific measure of expected default frequency (EDF) for non-financial firms is taken from Moody's Analytics. Macroeconomic indicators are taken from Eurostat (real GDP and HICP inflation) and Consensus Economics (expected value of inflation and real GDP growth one year ahead).

Finally, bank balance sheet data are taken from different commercial datasets - namely Bankscope, SNL, Bloomberg and Capital IQ - with the aim of maximising the sample size. This also makes it possible to check the consistency of the information provided by the four datasets and hence minimise misreporting and outliers.

Descriptive statistics for the main variables used in the estimation are reported in Table 1.

\footnotetext{
${ }^{12}$ See appendix 1 for stylised facts on loan-rate fixation periods across countries.
} 
For each variable, the table shows measures of central tendency and some selected percentiles describing the frequency distribution of data; the total number of observations available for each variable is given in the last column. The distribution across percentiles shows wide variation in the data over the sample. This variation is visible for all groups of variables in the table. For the regulatory capital ratio (i.e. the ratio of Tier 1 capital to risk-weighted assets), for example, the interquartile range goes from around 9 to $14 \%$; the same range for the NPL ratio (i.e. the ratio of non-performing loans to total loans) goes from $2.4 \%$ to $8.5 \%$.

Table 1: Descriptive statistics

\begin{tabular}{lcccccc}
\hline & Mean & Std. Dev. & 25th perc. & Median & 75th perc. & \# obs. \\
\hline \hline Financial variables & & & & & & \\
Short-term rate & 1.01 & 1.40 & 0.07 & 0.38 & 1.73 & 7,103 \\
Slope & 1.05 & 9.97 & 0.98 & 1.63 & 2.11 & 7,103 \\
VIX & 22.47 & 7.56 & 17.00 & 20.88 & 24.96 & 7,103 \\
Expected default frequency & 1.12 & 1.55 & 0.46 & 0.75 & 1.29 & 6,920 \\
Macroeconomic variables & & & & & & \\
Real GDP growth & 0.71 & 2.77 & -0.35 & 0.93 & 2.04 & 7,081 \\
Inflation & 1.30 & 0.86 & 0.80 & 1.26 & 1.73 & 7,103 \\
Expected real GDP growth & 1.23 & 1.02 & 0.71 & 1.33 & 1.78 & 6,799 \\
Expected inflation & 1.60 & 0.52 & 1.24 & 1.61 & 1.88 & 6,799 \\
Bank variables & & & & & & \\
Return on Assets (in basis points) & 41 & 76 & 12 & 36 & 71 & 7,103 \\
Net interest income (in basis points) & 36 & 23 & 21 & 35 & 48 & 5,462 \\
Non interest income (in basis points) & 35 & 48 & 16 & 27 & 42 & 2,173 \\
Provisions (in basis points) & 12 & 27 & 3 & 7 & 14 & 4,403 \\
NPL ratio & 6.71 & 6.96 & 2.44 & 4.12 & 8.52 & 3,765 \\
Tier1 capital ratio & 12.78 & 6.86 & 8.60 & 11.20 & 14.40 & 4,881 \\
Cost-to-income Ratio & 59.81 & 15.63 & 50.55 & 59.90 & 69.11 & 5,844 \\
\hline
\end{tabular}

Note: Data are at quarterly frequency covering the period Q1 2000 - Q2 2016. Variables are defined in percentage unless otherwise specified. Short-term rate is the three-month OIS, country-specific slope is the difference between ten- and two-year sovereign yields, euro area slope is the difference between ten- and twoyear OIS and sovereign spread is the difference between ten-year sovereign yields and the ten-year OIS. Expected real GDP growth is the one-year-ahead expectation obtained from Consensus Economics.

We start with a simple specification to measure the effects of monetary policy on bank profitability:

$$
R O A_{i, j, t}=\alpha_{i}+\beta_{1} \text { Level }_{t}+\beta_{2} \text { Slope }_{j, t}+\Omega X_{j, t}+\Phi Z_{i, j, t-1}+\varepsilon_{i, j, t}
$$

where ROA is the return on assets of a bank " $\eta$ " operating in a country " $j$ " at time " $P$ "; $\alpha_{i}$ are bank fixed effects; $\beta_{1}$ and $\beta_{2}$ are the coefficients associated with the level of a short-term interest rate (the three-month OIS) and the country-specific slope of the term structure - calculated as the difference between the yields on government bonds with a residual maturity of ten years and two years. Positive values for these two coefficients would imply that an increase in interest rates or a 
steepening of the term structure tends to lead to an increase in bank profitability. The model also includes a set of country- and bank-specific controls, $X_{j, t}$ and $Z_{i, j, t-1}$, respectively. Country specific controls include current and expected GDP growth, expected inflation, a measure of stock market volatility (VIX), and a forward looking measure of borrower risk (the expected default frequency, EDF). Bank-specific controls include the non-performing loan ratio (gross non-performing loans as a proportion of total loans), the Tier 1 capital ratio, the cost-to-income ratio and the lagged dependent variable. The vectors of coefficients $\Omega$ and $\Phi$ indicate the response of bank profitability to the controls used in the regression.

The impact of monetary policy on bank profitability in equation (2) is captured by assessing how changes in the short term rate and/or the slope of the term structure affect bank return on assets (ROA), i.e. by the coefficients $\beta_{1}$ and $\beta_{2}$. Importantly, the changes in bank profitability could be driven by many concurrent factors that can themselves influence the intended monetary policy stance and, therefore, the term structure of interest rates. That is, the changes in the ROA might be incorporating not only the effects of the monetary policy actions but also those of other confounding factors. We tackle this issue by controlling for changes in the current and expected macroeconomic environment, in addition to the set of controls usually employed in the banking literature analysing bank profitability. More precisely, the inclusion of the expected inflation and economic growth is intended to net out the effects of other factors that simultaneously affect both the monetary policy stance and bank return on assets. For example, a compression in ROA might reflect any news that are expected to have an adverse impact on economic conditions that in turn also lead to a decrease in policy rates, as the central bank's reaction function incorporates these news. In other words, as monetary policy is endogenous (reacts) to macroeconomic developments (current and expected), not including these variables in the specification would generate an omitted variable bias.

Important additional evidence might be obtained by interacting the level and the slope of the term structure with bank-specific variables. The regression model then becomes the following:

$$
\begin{aligned}
\text { ROA }_{i, j, t}=\alpha_{i}+ & \beta_{1} \text { Level }_{t}+\beta_{2} \text { Slope }_{j, t}+\Omega X_{j, t}+\Phi Z_{i, j, t-1}+\Gamma_{1}\left(\text { Level }_{t} \times Z_{i, j, t-1}\right) \\
& +\Gamma_{2}\left(\text { Slope }_{j, t} \times Z_{i, j, t-1}\right)+\varepsilon_{i, j, t}
\end{aligned}
$$

The expected sign of the elements of the $1 \times k$ coefficient vectors $\Gamma_{1}=\left[\gamma_{11} \ldots \gamma_{1 k}\right]$ and $\Gamma_{2}=$ $\left[\gamma_{21} \ldots \gamma_{2 k}\right]$ depends on the balance sheet variable considered. For example, a positive sign on the interaction term between the level of short-term interest rate and the cost-to-income ratio would mean that the most efficient banks (with a lower cost-to-income ratio) are the ones that benefit more from lower rates. Similarly, a negative coefficient on the interaction term between the slope of 
the term structure and the non-performing loan ratio would mean that a flattening of the yield curve would tend to be especially beneficial for banks with a higher share of non-performing loans.

The estimates of alternative specifications of equation (2) and (3) are reported in Table $2 .{ }^{13}$ Standard errors are clustered at the bank level in all regressions. ${ }^{14}$ The first column of the table shows that, in the absence of additional controls, the impact of monetary policy action on bank profitability is statistically significant: a reduction in the short-term interest rate (more akin to conventional policy) or a flattening of the yield curve (more akin to unconventional policy) tends to reduce bank profitability. However, periods of low interest rates tend to coincide with poor macroeconomic conditions, and controlling for the current macroeconomic outlook indeed weakens this relationship (column 2). Importantly, monetary policy is endogenous not only to current but also to future expected economic activity and, indeed, the relationship between interest rates and bank profitability breaks down when variables that control for the expected macroeconomic outlook are taken into account (column 3). ${ }^{15}$ While the slope of the term structure remains marginally significant, this is no longer the case once we control for forward looking borrower credit risk (column 4). ${ }^{16}$ Moreover, while adding bank-specific control variables leads to a decrease in the number of available observations, column 5 shows that results are robust to the use of this restricted sample. The role of expected macroeconomic developments is particularly relevant. A one standard deviation (i.e. one percentage point) increase in expected GDP growth increases ROA by about ten basis points. The logic behind this result is that a better expected macroeconomic outlook could increase current loan demand by stimulating investment which, in the euro area, is largely funded via bank intermediation. On the supply side, banks might be

\footnotetext{
${ }^{13}$ Appendix 2 reports several robustness exercises. These include showing that using the same sample across the five specifications reported in Table 2 does not change the results and that results are also robust to the use of a euro area measure of the slope of the yield curve (based on OIS rates) in place of the country-specific term structures.

${ }^{14}$ Our preferred estimation method is OLS. In principle, this could result in inconsistent estimates, as the lagged dependent variable is correlated with the error term due to the presence of time invariant fixed effects, as described by Nickell (1981). However, as the time dimension of our dataset is relatively long (the main sample covers 66 time periods) this effect should be negligible. Moreover, our results are robust to not including fixed effects and to the use of the GMM estimation, see Appendix 2. Furthermore, we studied the robustness of our results to different clustering; despite the fact that estimation with few clusters may yield a wrong inference (see e.g. Angrist and Pischke, 2009), our results are similar if we cluster by country (in addition to bank).

${ }^{15}$ Results would remain unchanged if current macroeconomic developments were excluded from columns 3 to 6 of Table 2. Therefore, the conclusion that expectations are crucial to understand the relationship between monetary policy and bank profitability is not driven by correlation between current and future expected macroeconomic developments.

${ }^{16}$ VIX and GDP lose statistical significance once we introduce expected GDP growth and EDF, which are the main two macro controls in terms of economic and statistical significance. In column 6 and 7 we introduce country*time fixed effects, which fully controls for different bank conditions across countries at the same time.
} 
induced to increase their lending to the non-financial private sector as the improved economic outlook will translate into increased company and household income, and hence lower credit risk.

Table 2: Monetary policy and balance sheet characteristics

\begin{tabular}{|c|c|c|c|c|c|c|c|}
\hline & (1) & (2) & (3) & (4) & (5) & (6) & (7) \\
\hline $\mathrm{ROA}_{i, j, t-1}$ & $\begin{array}{c}0.556 * * * \\
(0.0363)\end{array}$ & $\begin{array}{c}0.539 * * * \\
(0.0364)\end{array}$ & $\begin{array}{c}0.516^{* * *} \\
(0.0377)\end{array}$ & $\begin{array}{c}0.505^{* * *} \\
(0.0410)\end{array}$ & $\begin{array}{c}0.456 * * * \\
(0.0561)\end{array}$ & $\begin{array}{c}0.411^{* * *} \\
(0.0588)\end{array}$ & $\begin{array}{c}0.454 * * * \\
(0.130)\end{array}$ \\
\hline Short-term rate ${ }_{t}$ & $\begin{array}{c}0.0349 * * * \\
(0.00713)\end{array}$ & $\begin{array}{c}0.0195^{* * *} \\
(0.00745)\end{array}$ & $\begin{array}{c}0.00410 \\
(0.00756)\end{array}$ & $\begin{array}{l}-0.00340 \\
(0.00850)\end{array}$ & $\begin{array}{l}0.00376 \\
(0.0137)\end{array}$ & $\begin{array}{l}0.00336 \\
(0.0150)\end{array}$ & \\
\hline Slope $_{j, t}$ & $\begin{array}{c}0.00382^{* * *} \\
(0.00128)\end{array}$ & $\begin{array}{c}0.00313^{* *} \\
(0.00132)\end{array}$ & $\begin{array}{c}0.00243^{*} \\
(0.00137)\end{array}$ & $\begin{array}{l}0.000396 \\
(0.00137)\end{array}$ & $\begin{array}{c}0.00115 \\
(0.00130)\end{array}$ & $\begin{array}{c}0.00152 \\
(0.00154)\end{array}$ & \\
\hline $\mathrm{VIX}_{t}$ & & $\begin{array}{c}-0.00325^{* * *} \\
(0.000785)\end{array}$ & $\begin{array}{c}0.000533 \\
(0.000914)\end{array}$ & $\begin{array}{c}0.00213^{*} \\
(0.00113)\end{array}$ & $\begin{array}{c}0.00241 \\
(0.00185)\end{array}$ & $\begin{array}{c}0.00207 \\
(0.00204)\end{array}$ & \\
\hline Real GDP growth ${ }_{j, t}$ & & $\begin{array}{c}0.0154 * * * \\
(0.00484)\end{array}$ & $\begin{array}{c}-0.000996 \\
(0.00438)\end{array}$ & $\begin{array}{l}-0.00571 \\
(0.00464)\end{array}$ & $\begin{array}{l}-0.00683 \\
(0.00891)\end{array}$ & $\begin{array}{l}-0.00184 \\
(0.00927)\end{array}$ & \\
\hline Inflation $_{j, t}$ & & $\begin{array}{c}0.0394^{* *} \\
(0.0162)\end{array}$ & $\begin{array}{c}0.0262 \\
(0.0175)\end{array}$ & $\begin{array}{l}0.0327^{*} \\
(0.0178)\end{array}$ & $\begin{array}{c}0.0386 \\
(0.0391)\end{array}$ & $\begin{array}{c}0.0370 \\
(0.0401)\end{array}$ & \\
\hline Expected real GDP growth gr,t & & & $\begin{array}{c}0.0929 * * * \\
(0.0122)\end{array}$ & $\begin{array}{c}0.0828^{* * *} \\
(0.0109)\end{array}$ & $\begin{array}{c}0.110^{* * *} \\
(0.0186)\end{array}$ & $\begin{array}{c}0.112^{* * *} \\
(0.0181)\end{array}$ & \\
\hline Expected inflation $_{j, t}$ & & & $\begin{array}{l}0.0592 * \\
(0.0332)\end{array}$ & $\begin{array}{c}0.0687^{* *} \\
(0.0348)\end{array}$ & $\begin{array}{c}0.105^{*} \\
(0.0583)\end{array}$ & $\begin{array}{c}0.0808 \\
(0.0622)\end{array}$ & \\
\hline Expected default frequency $y_{j, t}$ & & & & $\begin{array}{c}-0.0593 * * * \\
(0.0202)\end{array}$ & $\begin{array}{c}-0.0644 * * \\
(0.0263)\end{array}$ & $\begin{array}{c}-0.0546^{* *} \\
(0.0258)\end{array}$ & \\
\hline NPL ratio $_{i, j, t-1}$ & & & & & & $\begin{array}{c}-0.0104^{* * *} \\
(0.00394)\end{array}$ & $\begin{array}{c}0.000854 \\
(0.0141)\end{array}$ \\
\hline Regulatory capital ratio ${ }_{i, j, t-1}$ & & & & & & $\begin{array}{c}0.00568 \\
(0.00378)\end{array}$ & $\begin{array}{l}0.0179 * * \\
(0.00780)\end{array}$ \\
\hline Cost-to-income ratio rij,t-1 $_{1}$ & & & & & & $\begin{array}{c}-0.00319 * * \\
(0.00157)\end{array}$ & $\begin{array}{c}0.00230 \\
(0.00433)\end{array}$ \\
\hline$\left({\left.\text { Short-term } \text { rate }_{t}\right) \times\left(\mathrm{NPL}_{\text {ratio }}, i, t,-1\right)}\right)$ & & & & & & & $\begin{array}{c}0.00575 \\
(0.00650)\end{array}$ \\
\hline$\left(\right.$ Slope $\left._{j, t}\right) \times\left(\right.$ NPL ratio $\left._{i, j, t-1}\right)$ & & & & & & & $\begin{array}{c}-0.00273^{* * *} \\
(0.000323)\end{array}$ \\
\hline$\left({\left.\text { Short-term } \text { rate }_{j, t}\right) \times(\text { Cost-to-income ratio }}_{i, j, t-1}\right)$ & & & & & & & $\begin{array}{l}0.00296^{*} \\
(0.00174)\end{array}$ \\
\hline$\left(\right.$ Slope $\left._{j, t}\right) \times\left(\right.$ Cost-to-income ratio rij,t-1 $\left._{1}\right)$ & & & & & & & $\begin{array}{c}0.000528^{* * *} \\
(0.0000838)\end{array}$ \\
\hline Bank FE & Yes & Yes & Yes & Yes & Yes & Yes & Yes \\
\hline Country*time FE & No & No & No & No & No & No & Yes \\
\hline Number of observations & 6768 & 6768 & 6768 & 6768 & 2974 & 2974 & 2974 \\
\hline $\mathrm{R}^{2}$ & 0.685 & 0.689 & 0.697 & 0.699 & 0.601 & 0.605 & 0.771 \\
\hline
\end{tabular}

Note: The dependent variable is the return on assets (ROA). Data are at quarterly frequency covering an unbalanced sample of 288 banks for the period Q1 2000 - Q2 2016. Standard errors clustered at bank level in parentheses: ${ }^{*} \mathrm{p}<.1, * * \mathrm{p}<.05,{ }^{* * *} \mathrm{p}<.01$. 
Moreover, expected future inflation is more economically (and statistically) relevant than current inflation (see e.g. column 5 of Table 2), which may be due to lower expected defaults (and therefore provisions) as it becomes cheaper for borrowers to pay back their loans (see Table 3). In any case, expected GDP growth and EDF are the main macro factors explaining bank profitability, both statistically and economically. ${ }^{17}$

When including also bank-specific variables, an average bank's profitability is still not found to react to changes in the level or the slope of the yield curve - see column 6 , our baseline specification. Important bank-specific control variables are the NPL ratio, the cost-to-income ratio and the regulatory capital ratio. Banks with a higher NPL ratio tend to show lower profitability: a one standard deviation (i.e. 7.4 percentage points) increase in the NPL ratio reduces ROA by 8 basis points.

This result is intuitive as bad loans do not generate income and lead to costs associated with provisions for credit losses as well as operational costs associated with their management and resolution. In line with previous studies (e.g. Athanasoglou et al., 2008; García-Herrero et al., 2009), we find that cost efficiency has a positive and highly significant impact on profitability: a one standard deviation (i.e. 25 percentage point) increase in the cost-to-income ratio reduces ROA by 6 basis points. This result suggests that operational efficiency is a major avenue to explore in order to improve bank profitability.

Finally, we test whether the effect of monetary policy on profitability depends on the cost efficiency or the credit quality of a bank's loan portfolio (column 7). We find a negative and significant value for the interaction terms between the level and slope of the term structure and the NPL ratio, implying that the higher the NPL, the more positive the impact of monetary policy easing on profitability. ${ }^{18}$ There could be different reasons that explain this. First, NPL are nonincome producing assets that still need to be funded. This means that lower interest rates, by decreasing funding costs, decrease the cost of holding NPL. Second, policy easing would decrease the cost of servicing debt, thereby exerting a positive influence on borrowers' ability to honour their commitments (and their probability of default).

We also find that the impact of monetary policy on bank profitability depends on the relative (operational) efficiency of a given bank. The coefficients on the interaction terms with the level and the slope of the term structure are both positive, suggesting that the effect of monetary policy easing on profitability is more positive in relative terms for banks with a lower cost-to-income ratio, i.e. with greater operational efficiency.

\footnotetext{
${ }^{17}$ In fact, results would remain broadly unchanged if current GDP and inflation were excluded from the regressions.

18 The slope (as compared to the level of short-term rates) may affect more bank differential behaviour as it captures both the long-term positions of bank assets and the short-term position of bank liabilities.
} 


\subsection{Components of bank profitability}

In order to empirically document the channels through which monetary policy actions are transmitted to bank profitability, the analysis presented in this section singles out the impact of changes in interest rates on the main components of profitability.

The impact on net interest income works via a price channel, i.e. the components of the net interest margin, and via a quantity channel, which is more closely related to the positive impact of the low interest environment on aggregated demand. The second component is non-interest income, driven mainly by capital gains, fees and commissions. This component plays a special role when QE policies are implemented as the impact on asset values in financial markets might generate sizeable capital gains. The third component is provisions. This is related to the macro effects of the policies and the associated impact on borrowers' credit quality.

Regression results derived from a panel model specification similar to the one used in equation 2 are reported in Table 3. The first three columns of the table present the results for the main components of bank profitability: net interest income (NII); non-interest income (NNI); and provisions (PROV); the last column recalls results for overall return on assets (ROA) as shown in column 4 of Table 2 above. All components are expressed as annualised percentage ratios of total assets.

The level of short-term interest rates is found to be positively associated with banks' net interest margins. This result, which is found also in other studies (e.g. English et al 2014 and Claessens et al 2017), is robust to controlling for expected macroeconomic conditions and credit risk. All else equal, a 100 basis point increase in the short-term rate is associated with an increase in banks' net interest margins of around 1 basis point in the same quarter. Taking into account the persistence of net interest margins (the estimated autoregressive coefficient is about 0.4 ), the overall impact of such a shock would be close to 2 basis points, which corresponds to around $5 \%$ of the mean of the net interest margin. Net interest margins are also found to be positively associated with economic growth. Conversely, low asset quality and high cost to income ratios tend to compress net interest margins.

Results for non-interest income are less clear-cut: no significant relationship is found with the level or slope of interest rates. The main determinants of non-interest income are changes in the valuation of securities held and fee and commission income. The first determinant in particular, should in principle benefit from a decline in interest rates, as lower yields are reflected in higher asset prices. It is however, important to note that while changes in the valuation of securities held by banks affect their economic value, they are reflected in the profit and loss account only if the securities are accounted at market values or if the capital gain/loss is realised. Since the share of 
securities held at market values is relatively small (see LHS panel of Figure A1.3) it is not surprising that the estimated coefficient is not statistically significant.

Table 3: Profitability components and monetary policy

\begin{tabular}{|c|c|c|c|c|}
\hline & $\begin{array}{c}(1) \\
\text { NII } \\
\end{array}$ & $\begin{array}{c}(2) \\
\text { NNI } \\
\end{array}$ & $\begin{array}{c}(3) \\
\text { PROV } \\
\end{array}$ & $\begin{array}{c}(4) \\
\text { ROA } \\
\end{array}$ \\
\hline$Y_{i, j, t-1}$ & $\begin{array}{c}0.352^{* * *} \\
(0.0722)\end{array}$ & $\begin{array}{c}0.0149 \\
(0.0432)\end{array}$ & $\begin{array}{c}0.136^{*} \\
(0.0762)\end{array}$ & $\begin{array}{c}0.411^{* * *} \\
(0.0588)\end{array}$ \\
\hline Short-term rate $_{t}$ & $\begin{array}{l}0.00598^{*} \\
(0.00345)\end{array}$ & $\begin{array}{c}0.00401 \\
(0.00950)\end{array}$ & $\begin{array}{c}0.00180 \\
(0.00472)\end{array}$ & $\begin{array}{l}0.00336 \\
(0.0150)\end{array}$ \\
\hline Slope $_{j, t}$ & $\begin{array}{l}-0.000300 \\
(0.000188)\end{array}$ & $\begin{array}{c}0.00139 \\
(0.00158)\end{array}$ & $\begin{array}{l}0.000986^{*} \\
(0.000506)\end{array}$ & $\begin{array}{c}0.00152 \\
(0.00154)\end{array}$ \\
\hline VIX $_{t}$ & $\begin{array}{c}0.000309 \\
(0.000426)\end{array}$ & $\begin{array}{l}-0.00165^{*} \\
(0.000853)\end{array}$ & $\begin{array}{c}-0.00136 \\
(0.000886)\end{array}$ & $\begin{array}{c}0.00207 \\
(0.00204)\end{array}$ \\
\hline Real GDP growth ${ }_{j, t}$ & $\begin{array}{c}0.00239 * * * \\
(0.000856)\end{array}$ & $\begin{array}{l}-0.00295 \\
(0.00295)\end{array}$ & $\begin{array}{l}-0.00303 \\
(0.00222)\end{array}$ & $\begin{array}{l}-0.00184 \\
(0.00927)\end{array}$ \\
\hline Inflation $_{j, t}$ & $\begin{array}{c}0.00693 \\
(0.00510)\end{array}$ & $\begin{array}{l}0.00606 \\
(0.0129)\end{array}$ & $\begin{array}{l}-0.00226 \\
(0.0137)\end{array}$ & $\begin{array}{c}0.0370 \\
(0.0401)\end{array}$ \\
\hline Expected real GDP growth $_{j, t}$ & $\begin{array}{c}0.00163 \\
(0.00323)\end{array}$ & $\begin{array}{c}0.0252^{* * *} \\
(0.00897)\end{array}$ & $\begin{array}{c}-0.0377^{* * *} \\
(0.0115)\end{array}$ & $\begin{array}{c}0.112^{* * *} \\
(0.0181)\end{array}$ \\
\hline Expected inflation $_{j, t}$ & $\begin{array}{l}-0.00318 \\
(0.00766)\end{array}$ & $\begin{array}{l}0.00248 \\
(0.0138)\end{array}$ & $\begin{array}{l}-0.0117 \\
(0.0295)\end{array}$ & $\begin{array}{c}0.0808 \\
(0.0622)\end{array}$ \\
\hline Expected default frequency $_{j, t}$ & $\begin{array}{l}-0.00226 \\
(0.00346)\end{array}$ & $\begin{array}{l}-0.0233 \\
(0.0169)\end{array}$ & $\begin{array}{l}0.0203^{* *} \\
(0.00794)\end{array}$ & $\begin{array}{c}-0.0546^{* *} \\
(0.0258)\end{array}$ \\
\hline NPL ratio ${ }_{i, j, t-1}$ & $\begin{array}{c}-0.00316^{* * *} \\
(0.000876)\end{array}$ & $\begin{array}{c}0.00342 \\
(0.00386)\end{array}$ & $\begin{array}{c}0.00626^{* * *} \\
(0.00237)\end{array}$ & $\begin{array}{c}-0.0104^{* * *} \\
(0.00394)\end{array}$ \\
\hline Regulatory capital ratio ${ }_{i, j, t-1}$ & $\begin{array}{l}0.00204 * \\
(0.00110)\end{array}$ & $\begin{array}{l}-0.00514 \\
(0.00516)\end{array}$ & $\begin{array}{c}-0.00322^{* *} \\
(0.00162)\end{array}$ & $\begin{array}{c}0.00568 \\
(0.00378)\end{array}$ \\
\hline Cost-to-income ratio ${ }_{i j, t-1}$ & $\begin{array}{c}-0.000783^{* * *} \\
(0.000218)\end{array}$ & $\begin{array}{l}-0.000511 \\
(0.000601)\end{array}$ & $\begin{array}{c}0.000203 \\
(0.000683)\end{array}$ & $\begin{array}{c}-0.00319^{* *} \\
(0.00157)\end{array}$ \\
\hline $\begin{array}{l}\text { Bank FE } \\
\text { Number of observations } \\
\mathrm{R}^{2}\end{array}$ & $\begin{array}{l}\text { YES } \\
2872 \\
0.771\end{array}$ & $\begin{array}{l}\text { YES } \\
1654 \\
0.322\end{array}$ & $\begin{array}{l}\text { YES } \\
2480 \\
0.403\end{array}$ & $\begin{array}{l}\text { YES } \\
2974 \\
0.605\end{array}$ \\
\hline
\end{tabular}

Note: Dependent variables: NII = net interest income as a percent of assets; NNI = non-interest income as a percent of assets; PROV $=$ provisions; $\mathrm{ROA}=$ return on assets. $Y_{t-1}$ denotes the lagged dependent variables. Data are at quarterly frequency covering an unbalanced sample of 288 banks for the period Q1 2000 - Q2 2016. Standard errors clustered at bank level in parentheses: ${ }^{*} \mathrm{p}<.1,{ }^{* *} \mathrm{p}<.05,{ }^{* * *} \mathrm{p}<.01$. 
Costs associated with loan loss provisions increase (decrease) following an upward (downward) shift or a steepening (flattening) of the yield curve, with the latter being statistically significant. As discussed in Section 2 above, this is likely to reflect the fact that lower interest rates allow for a decrease in borrowers' probability of default and in the associated loss given default.

Importantly, provisions are significantly affected by expected developments in economic growth and default frequencies. A one standard deviation (or 1.02 percentage point) increase in expected GDP leads to a reduction in provisions of 4 basis points, which corresponds to around one third of the provisions observed at the mean. An analogous decrease in the expected default frequency (1 standard deviation or $1.55 \%$ ) leads to a similar impact on provisions.

We also find that while expected GDP growth is more important for bank profits and three of its main components, current GDP growth is more important for net interest income. Note that noninterest income is partly driven by income and losses on market transactions (which therefore are affected by future economic activity) and provisions are also affected in great part by expected loan losses and hence future economic activity.

Overall, our results indicates that net interest income is negatively affected by a drop in the yield curve as also shown in Claessens et al. (2017). However, the decline in one component of bank profitability is not enough to generate a decrease in bank the overall profitability. In other words, the results emphasise the importance of considering jointly the dynamics of the components of bank profitability including banks' provision in addition to banks' net interest income.

\subsection{Keeping interest rates low for long}

The results presented above indicate that changes in short-term rates or in the slope of the yield curve do not significantly influence bank profitability once macroeconomic and bank-specific controls are appropriately taken into account. Nonetheless, there might be adverse effects on bank profitability if rates remain low for a long period of time. Indeed, following a decrease in interest rates, net interest margins are at first shielded due to the typically faster repricing of the outstanding amount of liabilities as compared to assets. Since assets tend to be longer term, changes in the interest rates applied on new business take longer to be reflected in the outstanding amount of loans. A protracted low interest rate environment could therefore be expected to be more detrimental for banks.

This subsection presents a test for this hypothesis within the regression framework.

In principle, there are various methods to capture the heterogeneous effects of monetary policy in a protracted low interest rate environment. Claessens et al. (2017), for example, identify such an environment by constructing a variable that counts the number of periods in which a reference interest rate is lower than a fixed threshold ( $1.25 \%$ for the three-month rate, in their case). Along these lines, the duration of the low interest rate environment might be captured by a variable that 
counts the periods when the rate on marginal refinancing operations (MRO) or the interbank overnight rate (EONIA) has been below a fixed threshold. In these cases, however, the results will depend on the particular (arbitrary) value used for the threshold. In order to avoid the need to define an ad hoc threshold, we construct a variable, defined as the sum of consecutive quarters in which residuals from an estimated Taylor rule are negative. The Taylor rule uses the three-month overnight index swap (OIS) rate as proxy for the monetary policy instrument and includes expectations for future inflation and for GDP growth one year ahead. The identification of the lowfor-long period based on Taylor residuals is therefore less arbitrary. In practice, we add three variables measuring the low-for-long to our baseline specification and present the results in Table 4.

Specifically, "Low for $\operatorname{long}\left(D_{M R O \leq 1.5}\right)$ " and "Low for $\operatorname{long}\left(D_{\text {Eonia }} \leq 1.25\right)$ " count the number of consecutive quarters in which the MRO and EONIA rates are below $1.5 \%$ and $1.25 \%$, respectively (the associated results are in column 2 and 3); "Low for long (Taylor rule)" is a variable that counts the number of consecutive quarters in which residuals of the forward-looking Taylor rule are negative (results are in column 4). ${ }^{19}$

Comparing column 1 with columns 2 to 4 of the table shows that results concerning the impact on profitability of changes in yields, the macroeconomic environment and bank-specific characteristics are robust to the inclusion of the low-for-long variable in the model specification.

Importantly, the coefficients for the low-for-long measures reported in columns 2 to 4 are all negative and statistically significant, suggesting that keeping rates low for an extend period of time might have negative consequences for bank profitability.

These results are broadly in line with the evidence reported by Claessens et al. (2017) for a large cross-section of banks covering several countries. However, the relatively small size of the coefficients of the low-for-long variables indicates that it would take a relatively long period of time for a monetary policy easing to exert a significant adverse effect on bank profitability. In addition, the materialisation of the negative consequences for bank profitability would be offset by the positive impact of low rates on real economic activity.

The stylised evidence on the impact of a protracted period of low interest rate on bank profitability is illustrated in Figure 4. Results obtained using our preferred specification based on Taylor rule residuals (Table 4, column 4) indicate that each additional year of low interest rates decreases bank profitability by about two basis points. The blue line in Figure 4 shows the cumulative impact on bank profitability of an additional year in a low interest rate environment assuming that the macroeconomic outlook remains unchanged. The estimate from column 4 of Table 4 implies that, after five years of low rates, the ROA of a median bank (which is equal to $0.4 \%$ ) is reduced by $25 \%$ (crossing the solid red line in the figure).

\footnotetext{
${ }^{19}$ Figure A1.4 in Appendix 1 displays the measures of low for long used in the estimations.
} 
Table 4: The impact of low-for-long interest rates on bank profitability

\begin{tabular}{|c|c|c|c|c|}
\hline & (1) & (2) & (3) & (4) \\
\hline $\mathrm{ROA}_{i, j, t-1}$ & $\begin{array}{c}0.409^{* * *} \\
(0.0590)\end{array}$ & $\begin{array}{c}0.404 * * * \\
(0.0590)\end{array}$ & $\begin{array}{c}0.404 * * * \\
(0.0590)\end{array}$ & $\begin{array}{c}0.407 * * * \\
(0.0588)\end{array}$ \\
\hline Short-term rate $_{t}$ & $\begin{array}{l}0.00436 \\
(0.0148)\end{array}$ & $\begin{array}{l}-0.0273 \\
(0.0210)\end{array}$ & $\begin{array}{l}-0.0241 \\
(0.0204)\end{array}$ & $\begin{array}{l}-0.0184 \\
(0.0202)\end{array}$ \\
\hline Slope $_{j, t}$ & $\begin{array}{c}0.00150 \\
(0.00152)\end{array}$ & $\begin{array}{c}0.00127 \\
(0.00153)\end{array}$ & $\begin{array}{c}0.00128 \\
(0.00153)\end{array}$ & $\begin{array}{c}0.00121 \\
(0.00153)\end{array}$ \\
\hline VIX $_{t}$ & $\begin{array}{c}0.00220 \\
(0.00199)\end{array}$ & $\begin{array}{l}0.000258 \\
(0.00207)\end{array}$ & $\begin{array}{l}0.000360 \\
(0.00207)\end{array}$ & $\begin{array}{c}0.00104 \\
(0.00214)\end{array}$ \\
\hline Real GDP growth ${ }_{j, t}$ & $\begin{array}{l}-0.00145 \\
(0.00962)\end{array}$ & $\begin{array}{l}0.00717 \\
(0.0100)\end{array}$ & $\begin{array}{l}0.00680 \\
(0.0100)\end{array}$ & $\begin{array}{l}0.00384 \\
(0.0103)\end{array}$ \\
\hline Inflation $_{j, t}$ & $\begin{array}{c}0.0330 \\
(0.0393)\end{array}$ & $\begin{array}{c}0.0300 \\
(0.0387)\end{array}$ & $\begin{array}{c}0.0302 \\
(0.0387)\end{array}$ & $\begin{array}{c}0.0318 \\
(0.0388)\end{array}$ \\
\hline Expected real GDP growth $_{j, t}$ & $\begin{array}{l}0.106^{* * *} \\
(0.0195)\end{array}$ & $\begin{array}{l}0.105 * * * \\
(0.0193)\end{array}$ & $\begin{array}{l}0.105 * * * \\
(0.0193)\end{array}$ & $\begin{array}{l}0.106^{* * *} \\
(0.0194)\end{array}$ \\
\hline Expected inflation $_{j, t}$ & $\begin{array}{c}0.0819 \\
(0.0621)\end{array}$ & $\begin{array}{c}0.0669 \\
(0.0620)\end{array}$ & $\begin{array}{c}0.0673 \\
(0.0620)\end{array}$ & $\begin{array}{c}0.0759 \\
(0.0628)\end{array}$ \\
\hline Expected default frequency $_{j, t}$ & $\begin{array}{c}-0.0587^{* *} \\
(0.0259)\end{array}$ & $\begin{array}{c}-0.0596^{* *} \\
(0.0251)\end{array}$ & $\begin{array}{c}-0.0596^{* *} \\
(0.0251)\end{array}$ & $\begin{array}{c}-0.0665^{* * *} \\
(0.0254)\end{array}$ \\
\hline NPL ratio $i, j, t-1$ & $\begin{array}{c}-0.00942^{* *} \\
(0.00401)\end{array}$ & $\begin{array}{c}-0.00802^{* *} \\
(0.00405)\end{array}$ & $\begin{array}{c}-0.00807^{* *} \\
(0.00405)\end{array}$ & $\begin{array}{c}-0.00936^{* *} \\
(0.00390)\end{array}$ \\
\hline Regulatory capital ratio ${ }_{i, j, t-1}$ & $\begin{array}{c}0.00573 \\
(0.00374)\end{array}$ & $\begin{array}{c}0.00872 * * \\
(0.00378)\end{array}$ & $\begin{array}{c}0.00859 * * \\
(0.00377)\end{array}$ & $\begin{array}{l}0.00770^{*} \\
(0.00395)\end{array}$ \\
\hline Cost-to-income ratio ${ }_{i, j, t-1}$ & $\begin{array}{c}-0.00324^{* *} \\
(0.00157)\end{array}$ & $\begin{array}{c}-0.00337 * * \\
(0.00156)\end{array}$ & $\begin{array}{c}-0.00336^{* *} \\
(0.00156)\end{array}$ & $\begin{array}{c}-0.00327^{* *} \\
(0.00156)\end{array}$ \\
\hline Low-for-long $\left(\mathrm{D}_{\mathrm{MRO} \leq 1.5}\right)_{t}$ & & $\begin{array}{c}-0.00695^{* * *} \\
(0.00226)\end{array}$ & & \\
\hline Low-for-long $\left(\mathrm{D}_{\text {Eonia } \leq 1.25}\right)_{t}$ & & & $\begin{array}{c}-0.00662^{* * *} \\
(0.00222)\end{array}$ & \\
\hline Low-for-long (Taylor rule) $)_{j, t}$ & & & & $\begin{array}{c}-0.00495^{* *} \\
(0.00221)\end{array}$ \\
\hline $\begin{array}{l}\text { Bank FE } \\
\text { Number of observations }\end{array}$ & $\begin{array}{c}\text { Yes } \\
2959\end{array}$ & $\begin{array}{c}\text { Yes } \\
2959\end{array}$ & $\begin{array}{c}\text { Yes } \\
2959\end{array}$ & $\begin{array}{l}\text { Yes } \\
2959\end{array}$ \\
\hline $\mathrm{R}^{2}$ & 0.602 & 0.604 & 0.604 & 0.603 \\
\hline
\end{tabular}

Note: The dependent variable is the return on assets (ROA). Data are at quarterly frequency covering an unbalanced sample of 288 banks for the period Q1 2000 - Q2 2016. "Low for long $\left(D_{M R O \leq 1.5}\right)$ " and "Low for $\operatorname{long}\left(D_{\text {Eonia }}\right.$ 1.25 $)$ " are variables that count the number of consecutive quarters in which the MRO and EONIA rates are below 1.5\% and 1.25\%, respectively; "Low for long (Taylor rule)" is a variable that counts the number of consecutive quarters in which residuals of a forward-looking Taylor rule are negative. Standard errors clustered at bank level in parentheses: ${ }^{*} \mathrm{p}<.1,{ }^{* *} \mathrm{p}<.05,{ }^{* * *} \mathrm{p}<.01$. 
The negative impact on profitability obtained with the other two low-for-long measures (i.e. using a threshold of $1.25 \%$ for the EONIA and 1.5\% for the MRO) in columns 2 and 3 is of similar magnitude. This evidence is akin to the mechanism described in Brunnermeier and Koby (2017) where the temporary positive effects on the repricing of the securities held by banks are over time increasingly offset by the negative impact on net interest margins.

The estimated impact can, however, be substantially different when the endogenous reaction of the macro variables associated with the low interest rate environment is taken into account. This is illustrated by the yellow line in Figure 4: a 1pp increase in the expected GDP (associated with an increase in bank profitability of about 10 basis points) would shift the blue line outward thereby contributing to a significant delay in the materialisation of the negative consequences for bank profitability associated with a low-for-long environment. For the first five years the change in expected GDP more than offsets the negative impact on profitability linked to the low-for-long; it would then take about ten years (twice as long as in the previous case) to reduce the profitability of the median bank by $25 \%$. Overall, the adverse impact of a protracted period of low rates on profitability is likely to be offset by the respective impact on loan loss provisions and intermediation volumes, a mechanism not envisaged in Brunnermeier and Koby (2017) and further explored in the next subsection.

Figure 4: Low-for-long, bank profitability and macroeconomic outlook

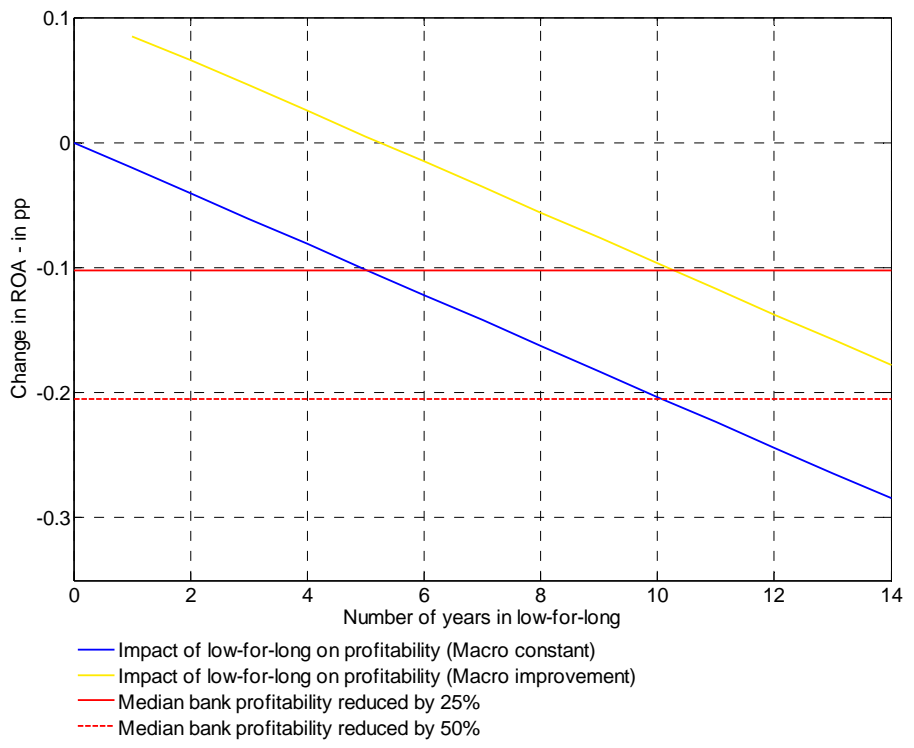

Notes: the chart illustrates the results of the estimates in column 4 of Table 4. The solid blue line indicates the impact on ROA of being in low-for-long and is constructed at unchanged macroeconomic outlook. The yellow line shows the change in ROA when although being in low-for-long, the macro outlook improves.

\subsection{The role of maturity transformation}

In this subsection, we explore the role played by maturity transformation in the relationship between monetary policy and bank profitability. We do so by augmenting the regression model 
expressed in equation 3 with a bank-specific measure of the difference between the average maturity of its assets and liabilities: the maturity gap (as defined in equation 1). This variable could play an important role in the transmission of changes in interest rates to bank profitability. For example, a positive sign on the interaction term between the slope of the yield curve and the maturity gap would mean that banks engaging more heavily in maturity transformation tend to benefit more in relative terms from a steepening of the term structure.

In order to obtain information on the average maturity of the different balance sheet items, we use bank data on income and balance sheet characteristics retrieved by matching data from S\&P Global Market Intelligence (formerly known as SNL Financial) with the iBSI (individual Balance Sheet Information), a proprietary dataset on bank balance sheet information available at a monthly frequency and maintained at the ECB. Given data limitations, the empirical analysis focuses on the period running from mid-2007 to end-2016. Importantly, the sample of banks covered by the dataset is chosen so as to be representative of the overall banking sector, thereby reflecting different business models, size and other bank characteristics. Table 5 contains summary statistics for the variables used in the estimation.

Table 5: Descriptive statistics for the restricted dataset

\begin{tabular}{lcccccc}
\hline & Mean & Std. Dev. & 25th perc. & Median & 75th perc. & \# obs. \\
\hline \hline Financial variables & & & & & & \\
Short-term rate & 0.60 & 1.15 & -0.03 & 0.16 & 0.60 & 3,566 \\
Country-specific slope & 0.74 & 13.63 & 1.17 & 1.72 & 2.19 & 3,566 \\
VIX & 23.41 & 8.39 & 18.89 & 20.88 & 25.60 & 3,494 \\
Expected default frequency & 1.09 & 1.28 & 0.51 & 0.77 & 1.20 & 3,494 \\
Macroeconomic variables & & & & & & \\
Real GDP growth & 0.04 & 2.37 & -1.31 & 0.62 & 1.55 & 3,294 \\
Inflation & 1.27 & 0.68 & 0.83 & 1.20 & 1.70 & 3,566 \\
Expected real GDP growth & 0.94 & 1.05 & 0.43 & 1.21 & 1.69 & 3,494 \\
Expected inflation & 1.55 & 0.51 & 1.21 & 1.56 & 1.87 & 3,494 \\
Bank variables & & & & & & \\
Return on Assets (in basis points) & 25 & 55 & 7 & 27 & 51 & 3,566 \\
Net interest income (in basis points) & 39 & 17 & 25 & 36 & 53 & 2,102 \\
Non-interest income (in basis points) & 23 & 13 & 13 & 23 & 32 & 2,087 \\
Provisions (in basis points) & 15 & 14 & 5 & 10 & 21 & 2,092 \\
NPL ratio & 5.75 & 4.50 & 2.54 & 4.48 & 7.46 & 2,297 \\
Tier1 capital ratio & 10.81 & 3.34 & 8.42 & 10.57 & 12.36 & 2,806 \\
Cost-to-Income Ratio & 61.51 & 15.37 & 50.78 & 61.04 & 71.41 & 3,143 \\
Liquid asset ratio & 30.49 & 16.26 & 18.24 & 26.84 & 38.03 & 2,402 \\
Maturity gap & 25.05 & 25.47 & 7.51 & 13.28 & 33.08 & 2,958 \\
\hline
\end{tabular}

Notes: Data are at quarterly frequency covering the period Q1 2007 - Q4 2016. Short-term rate is the threemonth OIS, country-specific slope is the difference ten- and two-year sovereign yields, euro area slope is the difference between ten- and two-year OIS and sovereign spread is the difference between ten-year sovereign yields and the ten-year OIS. Expected real GDP growth is the one-year-ahead expectation obtained from Consensus Forecast. 
Table 6: Monetary policy and maturity transformation

\begin{tabular}{|c|c|c|c|c|c|c|c|}
\hline & (1) & (2) & (3) & (4) & (5) & (6) & (7) \\
\hline $\mathrm{ROA}_{i, j, t-1}$ & $\begin{array}{c}0.165^{* * *} \\
(0.0327)\end{array}$ & $\begin{array}{c}0.141^{* * *} \\
(0.0334)\end{array}$ & $\begin{array}{c}0.112^{* * *} \\
(0.0319)\end{array}$ & $\begin{array}{c}0.101 * * * \\
(0.0328)\end{array}$ & $\begin{array}{l}0.0679 * \\
(0.0400)\end{array}$ & $\begin{array}{r}-0.00141 \\
(0.0428)\end{array}$ & $\begin{array}{c}0.0894 * * \\
(0.0403)\end{array}$ \\
\hline Short-term rate ${ }_{t}$ & $\begin{array}{c}0.0553^{* * *} \\
(0.0145)\end{array}$ & $\begin{array}{c}0.0323 * * \\
(0.0157)\end{array}$ & $\begin{array}{l}0.0166 \\
(0.0167)\end{array}$ & $\begin{array}{l}0.00634 \\
(0.0169)\end{array}$ & $\begin{array}{l}0.0352 \\
(0.0349)\end{array}$ & $\begin{array}{l}-0.0195 \\
(0.0254)\end{array}$ & \\
\hline Slope $_{j, t}$ & $\begin{array}{c}0.00448 * * * \\
(0.00123)\end{array}$ & $\begin{array}{c}0.00406 * * * \\
(0.00127)\end{array}$ & $\begin{array}{c}0.00290^{* *} \\
(0.00126)\end{array}$ & $\begin{array}{l}0.000853 \\
(0.00153)\end{array}$ & $\begin{array}{c}0.00123 \\
(0.00166)\end{array}$ & $\begin{array}{l}0.000926 \\
(0.00148)\end{array}$ & \\
\hline VIX $_{t}$ & & $\begin{array}{c}-0.00583^{* * *} \\
(0.00161)\end{array}$ & $\begin{array}{l}0.000583 \\
(0.00176)\end{array}$ & $\begin{array}{c}0.00164 \\
(0.00176)\end{array}$ & $\begin{array}{c}0.00187 \\
(0.00253)\end{array}$ & $\begin{array}{c}-0.00654 * * * \\
(0.00236)\end{array}$ & \\
\hline Real GDP growth ${ }_{j, t}$ & & $\begin{array}{c}0.0217 * * * \\
(0.00611)\end{array}$ & $\begin{array}{l}-0.00330 \\
(0.00615)\end{array}$ & $\begin{array}{l}-0.00769 \\
(0.00556)\end{array}$ & $\begin{array}{l}-0.00781 \\
(0.00645)\end{array}$ & $\begin{array}{l}0.0119 * \\
(0.00624)\end{array}$ & \\
\hline Inflation $_{j, t}$ & & $\begin{array}{l}-0.0163 \\
(0.0205)\end{array}$ & $\begin{array}{l}0.0425^{*} \\
(0.0219)\end{array}$ & $\begin{array}{l}0.0365^{*} \\
(0.0207)\end{array}$ & $\begin{array}{l}0.0500^{*} \\
(0.0258)\end{array}$ & $\begin{array}{l}0.0467 * \\
(0.0263)\end{array}$ & \\
\hline 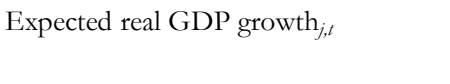 & & & $\begin{array}{c}0.158^{* * *} \\
(0.0191)\end{array}$ & $\begin{array}{c}0.134^{* * * *} \\
(0.0218)\end{array}$ & $\begin{array}{c}0.115^{* * *} \\
(0.0302)\end{array}$ & $\begin{array}{c}0.123 * * * \\
(0.0281)\end{array}$ & \\
\hline Expected inflation $_{j, t}$ & & & $\begin{array}{c}0.0617 * * \\
(0.0306)\end{array}$ & $\begin{array}{c}0.0735^{* *} \\
(0.0312)\end{array}$ & $\begin{array}{l}0.0402 \\
(0.0553)\end{array}$ & $\begin{array}{l}-0.0370 \\
(0.0531)\end{array}$ & \\
\hline Expected default frequency $_{j, t}$ & & & & $\begin{array}{c}-0.0671 * * * \\
(0.0249)\end{array}$ & $\begin{array}{c}-0.0814 * * \\
(0.0397)\end{array}$ & $\begin{array}{l}-0.0691 * \\
(0.0399)\end{array}$ & \\
\hline NPL ratio $_{i, j, t-1}$ & & & & & & $\begin{array}{c}-0.0471 * * * \\
(0.0101)\end{array}$ & $\begin{array}{c}-0.0264^{* *} \\
(0.0103)\end{array}$ \\
\hline Regulatory capital ratio $_{i, j, t-1}$ & & & & & & $\begin{array}{c}-0.0135 \\
(0.00872)\end{array}$ & $\begin{array}{l}0.00568 \\
(0.0120)\end{array}$ \\
\hline Cost-to-income ratio $_{i, j, t-1}$ & & & & & & $\begin{array}{l}-0.00332 \\
(0.00243)\end{array}$ & $\begin{array}{c}-0.000971 * \\
(0.000451)\end{array}$ \\
\hline Liquid asset ratio ${ }_{i, j, t-1}$ & & & & & & $\begin{array}{l}-0.00609 \\
(0.00543)\end{array}$ & $\begin{array}{l}-0.00163 \\
(0.00507)\end{array}$ \\
\hline Maturity gap $\mathrm{p}_{i, j, t-1}$ & & & & & & $\begin{array}{c}0.00372 * * \\
(0.00143)\end{array}$ & $\begin{array}{l}0.00418^{*} \\
(0.00216)\end{array}$ \\
\hline$\left(\right.$ Short-term rate $\left.{ }_{t}\right) \times\left(\right.$ Maturity gap $\left._{i, j, t-1}\right)$ & & & & & & & $\begin{array}{l}0.000107 \\
(0.00159)\end{array}$ \\
\hline$\left(\right.$ Slope $\left._{j, t}\right) \times$ (Maturity gap $\left.p_{i, j, t-1}\right)$ & & & & & & & $\begin{array}{c}0.000696^{* *} \\
(0.000273)\end{array}$ \\
\hline Bank FE & Yes & Yes & Yes & Yes & Yes & Yes & Yes \\
\hline Country*time FE & No & No & No & No & No & No & Yes \\
\hline Number of observations & 2,271 & 2,271 & 2,271 & 2,271 & 845 & 845 & 845 \\
\hline $\mathrm{R}^{2}$ & 0.418 & 0.429 & 0.468 & 0.472 & 0.432 & 0.467 & 0.646 \\
\hline
\end{tabular}

Note: The dependent variable is the return on assets (ROA). Data are at quarterly frequency covering an unbalanced sample of 234 banks for the period Q1 2007 - Q4 2016. Standard errors clustered at bank level in parentheses: $* \mathrm{p}<.1,{ }^{* *} \mathrm{p}<.05, * * * \mathrm{p}<.01$. 
Estimation results are reported in Table 6. Similarly to Table 2, results show that, by influencing either the short-term rate or the slope of the term structure, monetary policy is found to have a significant impact on bank profitability if no additional controls are included in the specification (column 1).

Also in line with results shown in Subsection 3.1, current and future macroeconomic developments remain important drivers of bank profitability, and the coefficients for the short-term rate and the slope lose statistical significance when adding macroeconomic controls (column 2 to 5). The impact on profitability of the cost-to-income ratio and the NPL ratio has similar sign and magnitude to the coefficients obtained using the longer sample: low cost efficiency and high nonperforming loans tend to compress bank profitability (column 6).

The positive coefficient on the maturity gap reflects the idea that, all other things being equal, increased maturity transformation translates into higher profitability (see English et al., 2014). An average bank will see its ROA rise by about 10 basis points following an increase in its maturity gap by one standard deviation (i.e. 25 months). Moreover, we investigate whether the impact of changes in the level and the slope of the term structure depend on the maturity gap. The results in column 5 show that the profitability of banks that engage more heavily in maturity transformation has a more positive reaction to a steepening of the yield curve in relative terms. A bank with a maturity gap that is one standard deviation above the sample average sees its profitability increase by two basis points in response to a 100 basis point steepening of the yield curve.

In principle, the impact of monetary policy action on bank profitability through maturity transformation would be mitigated if banks used derivatives to hedge exposures to interest rate risk. Recent evidence by Begenau et al. (2015), however, suggests that the extent to which US banks use interest rate derivatives to hedge exposures to interest rate is limited. For the euro area, Hoffmann et al. (2017) find that banks use derivatives to reduce their banking book exposures to interest rate risk by $25 \%$, on average. This evidence on US and European banks suggests that these financial intermediaries do not fully hedged for interest rate risk (which is also confirmed in the last section of the paper, as if banks were fully hedged, then there should not be an impact from monetary policy surprises on bank stocks and CDS).

\section{Evidence from a stylised macro model}

We complement the micro evidence discussed so far by investigating in this section the macroeconomic implications of changes in monetary conditions on bank profits (and their main components) using a dynamic multivariate macro model that incorporate feedback effects from monetary policy to GDP growth and hence to bank conditions. In particular, we analyse impact on bank profitability of a monetary policy easing through the lens of a dynamic model estimated at 
euro area level. The model is Bayesian vector-autoregression (BVAR) thought to capture the main channels through which monetary policy affect bank profitability. The variables included in the model are eleven: return on assets (ROA), net interest income (NII), non-interest income (NNI), loan loss provisions (Provisions), lending rates to non-financial corporations (NFC), loan volumes to NFC, real GDP, HICP inflation, and interest rates with a remaining maturity of 1-day (i.e. the Eonia rate), 5-year, and 10-year. The variables enter the BVAR in log-levels (or levels for variables already expressed in terms of rates) with 5 lags, for a sample period ranging from the 1999Q1 to 2017Q1.20

In order to identify the effects of a monetary policy shock, we use a recursive identification scheme where the interest rates are ordered last. More precisely, in order to capture the impact of monetary policy in a low interest rate environment we simulate the response of the variables included in the model to a policy easing shock that resembles the effect of a quantitative easing $(\mathrm{QE})$ policy on the term structure of interest rates, i.e. the effects are increasing in the remaining maturity of the underlying bonds (see Altavilla, Carboni, and Motto, 2015). More precisely, the easing shock consists of a decrease in the 10-year yields of 100bps with a simultaneous smaller reduction on the 5-year and the Eonia amounting to 40 and 5 basis points, respectively. The shock is temporary and dies out over time with a decay that is assumed to be the same across maturities and fixed at 0.9.

Figure 5 shows the reaction of the macro variables to the policy shock. Following an easing shock that flattens the term structure, real GDP, lending volumes and HICP inflation increase reflecting improved economic prospects associated with better financial conditions. The degree of accommodation is also passed-through to borrowing conditions thereby compressing lending rates to firms. These effects are all statistically significant.

Improvements in real economic activity as well as changes in the yield curve are transmitted to bank profitability and its components as illustrated in Figure 6. The reduction in interest rates on a large set of financial assets at different maturities is reflected in lower bank net interest income. A possible explanation for this reduction is that savings in funding costs do not fully offset lower interest income in the context of a flatter yield curve, as banks tend to fund longer-term assets with shorter-term liabilities, thereby engaging in maturity transformation. This is compounded by the

\footnotetext{
${ }^{20}$ For the estimation of the VAR, we address the high-dimensional data problem (eleven variables, five lags, and a quarterly sample starting in 1999:Q1) by using Bayesian shrinkage, as suggested in De Mol et al. (2008). In more detail, we use Normal-Inverse Wishart prior distributions: we impose the so-called Minnesota prior, according to which each variable follows a random walk process, possibly with drift (Litterman, 1979). Moreover, we impose two sets of prior distributions on the sum of the coefficients of the VAR model: the "sum-of-coefficients" prior, originally proposed by Doan et al. (1984), and an additional prior that was introduced by Sims (1993), known as the "dummy-initial-observation" prior. The hyper-parameters controlling for the informativeness of the prior distributions are treated, as suggested in Giannone et al. (2015), as random variables and are drawn from their posterior distribution, so that we also account for the uncertainty surrounding the prior set-up in our evaluation.
} 
fact that deposit rates tend to be particularly sticky at very low levels of interest rates. At the same time, non-interest income instead increases, possibly reflecting higher capital gains due to increases in the market value of sovereign bonds held by banks.

Figure 5: Impact of a QE-type policy shock on macroeconomic outlook
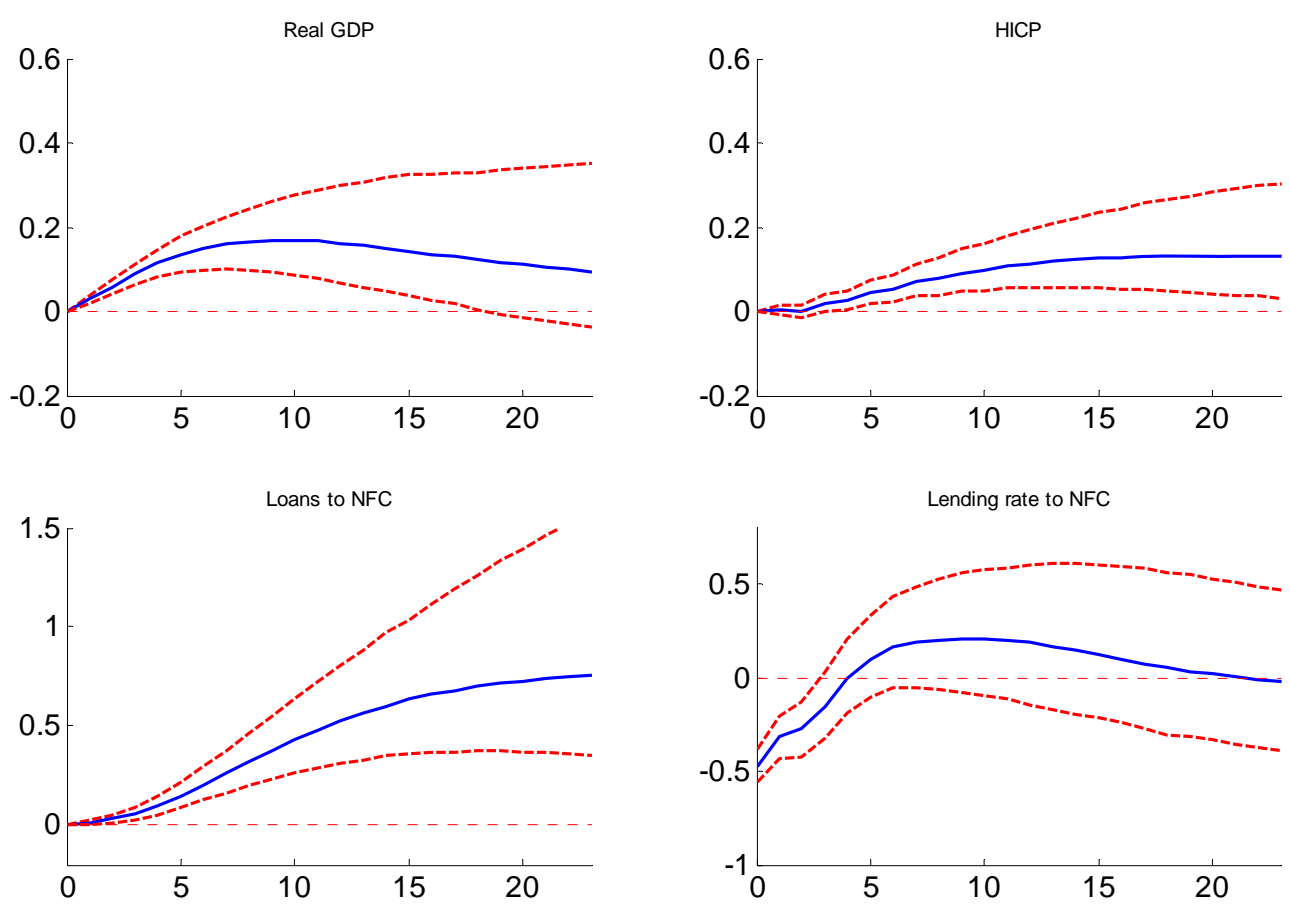

Notes: The horizontal axis refers to quarters after shock. The solid blue line represents the median response, while the dotted red lines refer, respectively, to the 16th -84 th percentile of the posterior distribution of the impulse-response functions.

In addition, the monetary policy shock has a delayed, significant, hump shaped effect on loan loss provisions. The estimated gradual decrease in provisions reaches the minimum after one year and a half indicating a lagged reaction of credit quality and intermediation volumes possibly linked to the feedback from improved economic outlook. In principle, this impact might be driven by two different channels. First, the pass-through to lending rates of the compression of yields on a large number of financial assets leads to a decrease in debt service costs for households and firms, in particular for variable-rate contracts. Second, improved borrower quality due to income and wealth effects following positive changes in the macro outlook reduce the probability of both firms and households defaulting on a loan (PD). At the same time, increased collateral values contribute a decrease in the losses incurred by banks when borrowers default on their loans (LGD). Finally, there is an effect that can work in the opposite direction. Compressed risk premia against the background of low interest rates imply that more projects become profitable. While this is an intended effect of the policy, if it is excessive, the increase in the risk inherent in new loans will lead 
to increased defaults in the medium to long run, especially for weaker banks (see Jimenez et al., 2014 - credit risk-taking channel). While we do not directly observe excessive risk taking by banks, the results suggest that overall this potential negative effect could, in principle, be offset by the benefits described above.

Overall, the impact of monetary policy on bank profitability is found to be broadly neutral, and for most of the simulation horizon not statistically significant, reflecting the evidence that the effects on different components of bank profitability tend to largely offset each other.

Figure 6: Impact of a QE-type policy shock on bank profitability
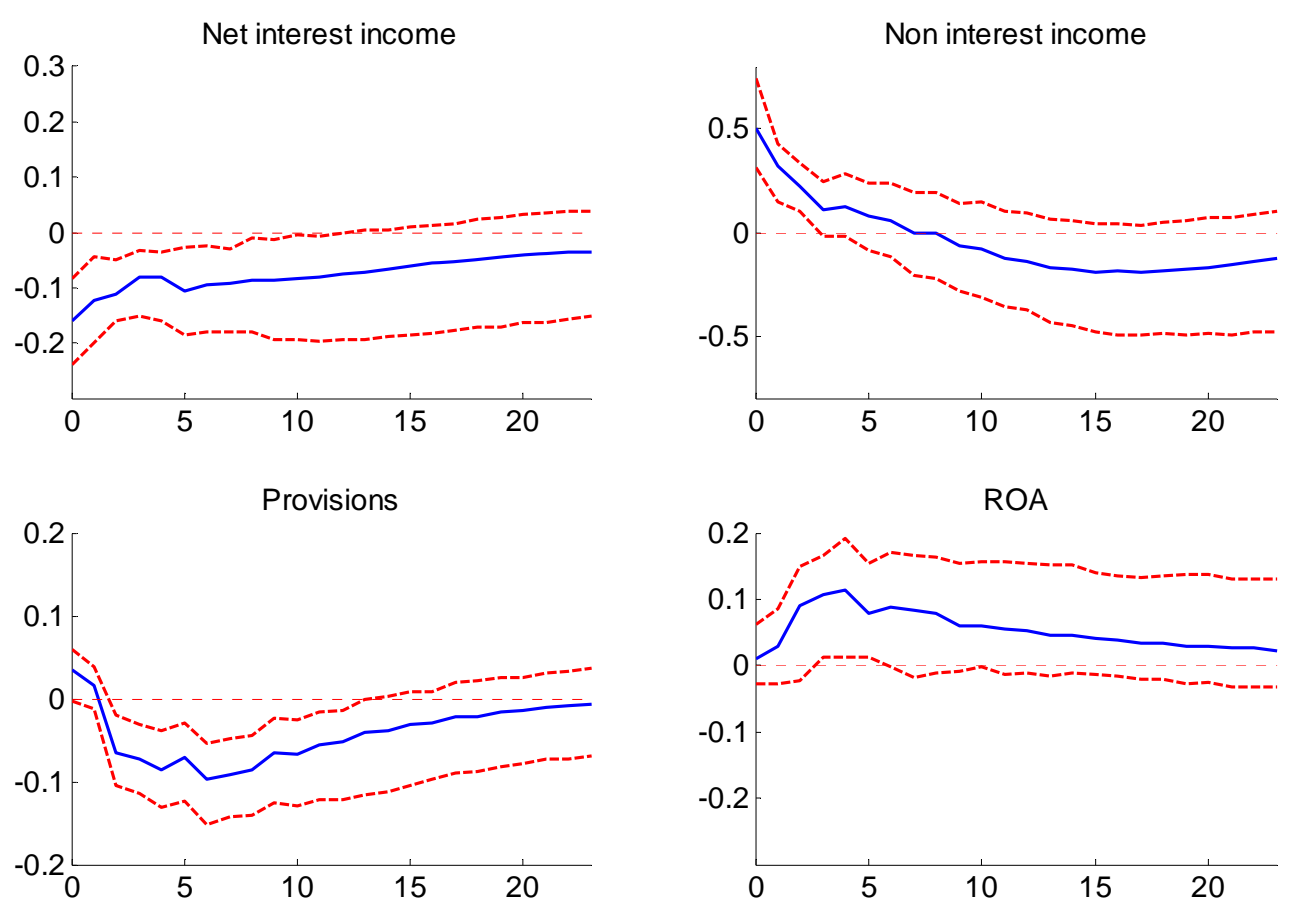

Notes: The horizontal axis refers to quarters after shock. The solid blue line represents the median response, while the dotted red lines refer, respectively, to the 16 th -84 th percentile of the posterior distribution of the impulse-response functions.

\section{Bank equity valuations and credit risk}

In this section, the analysis moves from accounting measures of bank profitability to bank equity valuations that implicitly reflect market expectations of future profitability. Specifically, since bank equity prices reflect all the information currently available to stock market participants, they represent a forward-looking measure of profitability. The analysis provides empirical evidence on the reaction of bank-level stock returns to unexpected changes in the level and slope of the yield curve associated with the announcement of recent, non-standard monetary policy measures by the ECB. While equity prices are relevant for shareholders, bank equity in Europe has in general only accounted for around $5 \%$ of total assets, whereas the vast majority of bank activity is financed by 
debt. Therefore, in order to cover the impact of policies for major stakeholders of banks (including debtholders), the analysis also considers the reaction of the bank-credit risk (as summarised by the CDS) to these announcements. While stock returns and CDS tend to be highly correlated, the information they provide might differ substantially. Stock prices reflect the market value of banks, whereas CDS spreads measure market participants' perception of banks' credit risk. As such, the former is relevant for shareholders, while the latter is relevant for debtholders, ultimately including depositors.

We use high-frequency information at individual bank level on stock prices and CDS over the period from January 2007 to September 2016. The number of banks considered for each country and the representativeness of the sample are shown in Table 7.

Table 7: Sample representativeness

\begin{tabular}{lccc}
\hline Country & \multicolumn{3}{c}{ \# banks } \\
\hline \hline & Stock & CDS & Stock \& CDS \\
\cline { 2 - 4 } Austria & 5 & 5 & 1 \\
Belgium & 2 & 3 & 2 \\
Cyprus & 2 & 0 & 0 \\
Germany & 6 & 9 & 2 \\
Spain & 8 & 8 & 6 \\
Finland & 1 & 0 & 0 \\
France & 4 & 7 & 4 \\
Greece & 4 & 4 & 4 \\
Ireland & 2 & 4 & 2 \\
Italy & 11 & 7 & 6 \\
Luxembourg & 0 & 1 & 0 \\
Malta & 2 & 0 & 0 \\
Netherlands & 4 & 5 & 4 \\
Portugal & 3 & 4 & 3 \\
\hline Total & 54 & 57 & 34 \\
Share of market cap $(\%)$ & 96 & 93 & 93 \\
\hline
\end{tabular}

Note: The table shows the number of bank by country for which we have information on stock prices (second column) and CDS (third column). The last column gives the number of banks for which we have information on both stock prices and CDS.

Figure 7 depicts daily developments in bank stock prices (right panel) and CDS (left panel) over time for the cross-sectional distribution of banks available in the sample, as in a fan chart representation. The solid red line that goes through the areas is (for each day) the sample median.

The shaded areas comprise $95 \%$ of the cross-sectional distribution of banks around it: the interquartile range across banks is the darkest shade, and the next shade represents $68 \%$ of the distribution, and so on, until the $95 \%$ is covered. Three periods are clearly visible during the sample. The first one is related to the global financial crisis following the collapse of Lehman Brothers. After September 2007, CDS spreads started to widen and stock prices tumbled. The same 
dynamics, amplified even more, are observed during the sovereign debt crisis (2011-2012). Finally, there has been a further decline in stock prices and a slight deterioration in the market perception of bank risk over the 2015 and part of the 2016 that have significantly reverted in the last part of the sample.

The observed developments make it particularly challenging to identify the effects of monetary policy due to endogeneity and simultaneity issues. Falling stock prices in response to lower interest rates (leading to a strong positive correlation between the two) could suggest that monetary easing compresses stock prices. The same reasoning applies to CDS. Of course, correlation is not causation, so movements in stock prices can only be interpreted as being due to policy action if monetary shocks are correctly identified. Being forward-looking, moreover, financial markets only tend to react to information about policy changes if these changes are unanticipated. Therefore, to correctly identify the impact of monetary policy, the unexpected component of the policy change must be isolated and confounding factors must be adequately controlled for.

Figure 7: Bank stock prices and CDS
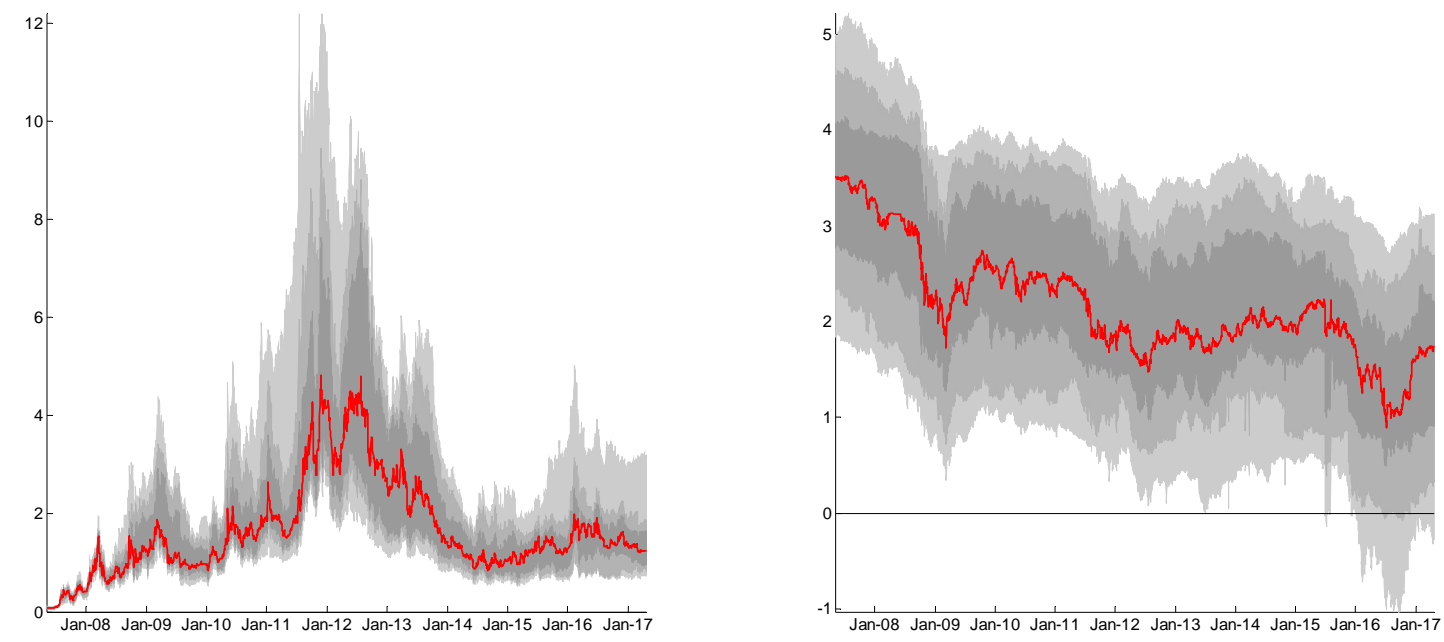

Note: The chart shows the daily dispersion in bank stock prices (right panel) and CDS (left panel) for the sample of banks included in the analysis. The solid red line represents (for each day) the median of the cross-section of banks. Similarly, the shaded areas comprise the interquartile range, the $68 \%$ and the $95 \%$ of the cross-sectional distribution of banks.

For these reasons, we identify the effects of monetary policy announcements using highfrequency data in a conventional event study approach (see Bernanke and Kuttner, 2005). The idea is that changes in financial asset valuations occurring in a small window around a given policy announcement capture the (efficient) market reaction to the arrival of new information, thereby 
reflecting the causal impact of the policy. ${ }^{21}$ In our analysis, we concentrate on a two-day event window. ${ }^{22}$ The regression model we estimate takes the following form:

$$
\Delta y_{i, t}=\sum_{j=1}^{k} \lambda_{i, j} D_{j, t}+\gamma_{i} \text { News }_{t}+\varepsilon_{t}
$$

where $t$ and $i$ index days and individual banks, and the dependent variable $\left(\Delta y_{i, t}\right)$ is the daily change in stock prices or CDS. $D_{j, t}$ denotes a set of event dummy variables, each taking the value 1 at the date of the policy announcement selected and 0 otherwise. The relevant set of events includes all calendar days when non-standard monetary policies were announced by the ECB.23 $N e w s_{t}$ is a vector including a set of (standardised) surprise components from releases of marketmoving variables for both the euro area and the United States. ${ }^{24}$

The effect of the policy announcement for each event over a one-day window is measured by $\lambda_{j}$. Estimates are obtained by ordinary least squares, and statistical significance is assessed using heteroscedasticity-robust standard errors. The sample period is from the start of June 2007 to the end of September 2016. In order to highlight the impact of monetary policy announcements on both CDS and stock prices, we restrict the sample of banks considered in the analysis to those for which we have this information in both cases. The results are illustrated in Figure 8.

For each of the eight selected policy events and for each bank (denoted by a blue circle in the charts), the $\mathrm{x}$-axis reports the change in stock prices while the $\mathrm{y}$-axis reports the change in CDS spreads. The results are striking: for the vast majority of banks, stock prices increased and CDS spreads narrowed following all major monetary policy announcements.

This suggests that financial market participants reacted positively to the announcement of the new policies. The only exception is the announcement of the recalibration of the APP scheme in December 2015, which is associated with a fall in stock prices (second-to-last chart on the right of the figure). This is, however, easy to understand, as financial market participants interpreted the December policy decision as delivering lower-than-expected accommodation compared with what they had anticipated and factored into stock prices. The policy decision therefore elicited an opposite reaction in financial markets when announced. This announcement, however, is also characterised by a heterogeneous response of bank CDS.

\footnotetext{
${ }^{21}$ See Gürkaynak, Sack and Swanson (2005a), Altavilla and Giannone (2017) and Gürkaynak and Wright (2013).

${ }^{22}$ Expanding the event window to two days does not change the results.

${ }^{23}$ Appendix 3 lists the set of events selected.

${ }^{24}$ More specifically, the surprises are the difference between the data released during the event-window days and the consensus forecasts collected immediately beforehand. Data on the selected variables and the corresponding forecasts are from Bloomberg. See Altavilla and Giannone (2017) on the "controlled" eventstudy methodology.
} 
Figure 8: Change in stock price and CDS due to monetary policy

SMP - 10 May 2010

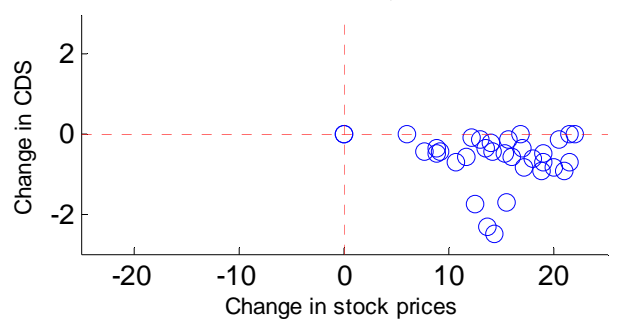

TLTRO - 5 June 2014

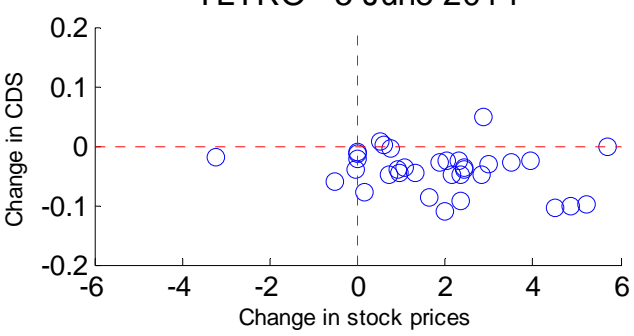

APP - 22 January 2015

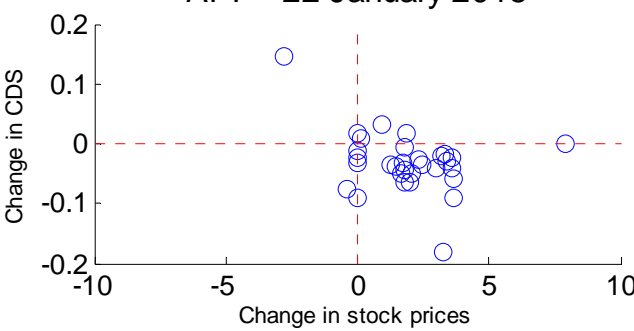

APP - 10 March 2016

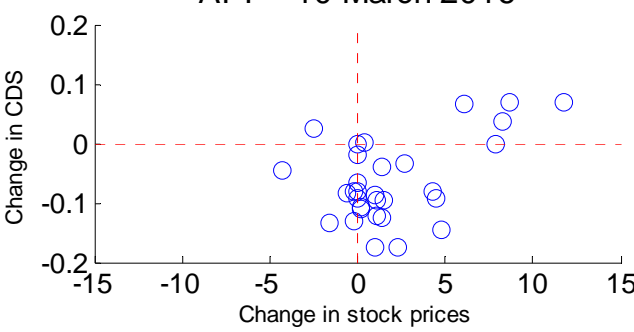

OMT - 26 July 2012

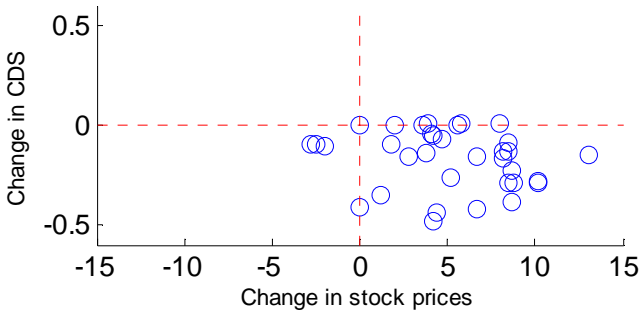

NIR - 4 September 2014

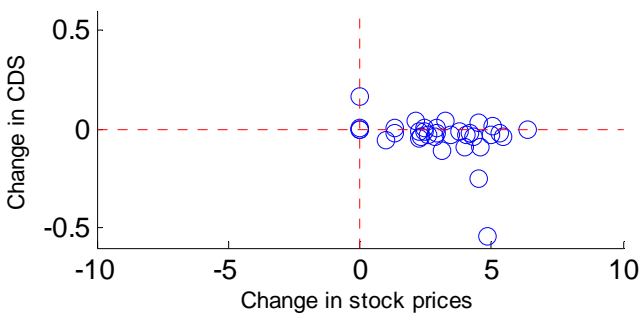

APP - 3 December 2015

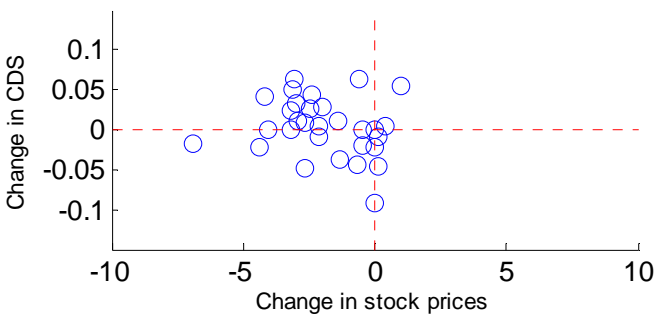

APP - 8 December 2016

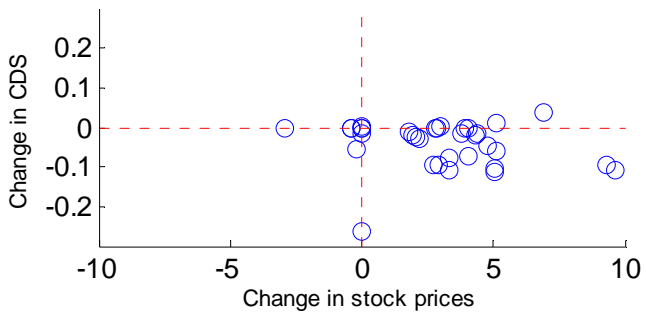

Note: Each figure corresponds to a monetary policy announcement. SMP is the Security Markets Programme; OMT is the Outright Monetary Transactions programme; VLTRO is the three-year, Very Long-Term Refinancing Operations; TLTRO is the Targeted Longer-Term Refinancing Operations; NIR is the Negative Interest Rate policy; APP is the Asset Purchase Programme.

In principle, there are different reasons why a monetary easing may lead to an increase in stock prices. First, financial markets might perceive that the looser policy may generate an increase in expected future dividends. Second, accommodative policy may be associated with a decline in the discount rate, being the future expected real interest rates used to discount the dividends. Third, the policy easing may compress the equity premium. In order to exclude the effect related to the discount factor, we repeat the same exercise for stock market indices of different industries. As the 
effect of the discount factor should affect all industries equally, the remaining differences should be attributed to changes in the equity premium associated with holding stocks or to the expected future dividends.

Figure 9 shows that, although industry-based portfolios tend to react in a similar direction, the size of the response may vary substantially.

Overall, the index for the banking sector exhibits the largest response to most of the events. For utilities and insurance companies - which tend to be significantly less leveraged than banks - the effect of monetary policies is more muted. These results corroborate the previous evidence on the positive impact of non-standard measures on bank stock valuations (e.g. English et al., 2014).

Figure 9: Changes in stock price indices for different aggregates

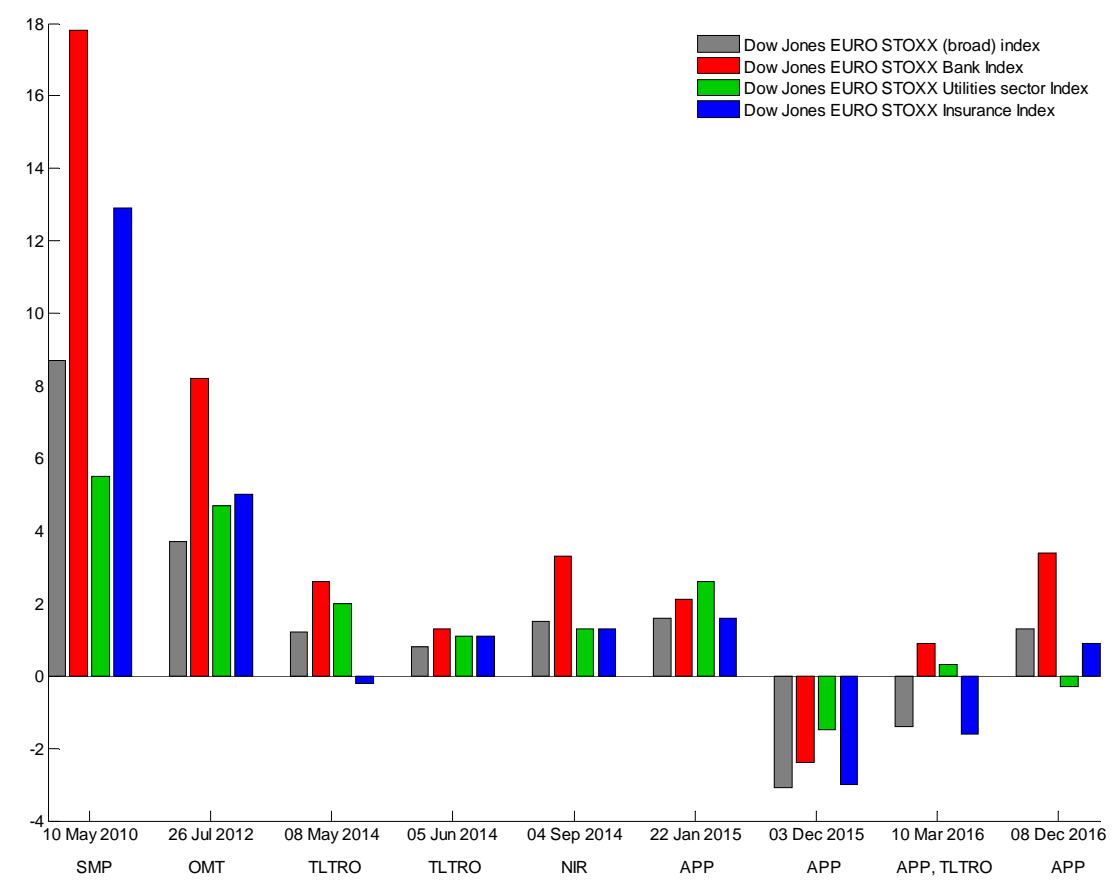

Note: The figure shows the changes in selected stock price indices after nonstandard monetary policy announcements.

Finally, we carry out an empirical analysis of the impact of recent announcements of non-standard measures on individual bank stock returns and changes in bank CDS spreads. ${ }^{25}$ More specifically, we estimate the average reaction of these variables to interest rate surprises using the following regression model:

${ }^{25}$ We concentrate on the policy announcements made since the onset of the financial crisis as listed in Table A.3.1. 


$$
\mathrm{y}_{i, j, t}=\phi_{0}+\phi_{1} \text { Surprise }_{\text {Level }, t}+\phi_{2} \text { Surprise }_{\text {Slope }, j, t}+\Theta \text { Controls }_{i, j, \tau}+\eta_{i, j, t}
$$

where $\mathrm{y}_{i, j, t}$ denotes the one-day stock return/change in CDS spread of bank $i$ operating in country $j$ on the ECB Governing Council announcement date $t$, Surprise Level, $t_{\text {is }}$ is the surprise component associated with the short-term interest rate (the 3-month OIS rate); while Surprise $_{\text {Slope }, j, t}$ is the slope surprise. The country-specific slope of the term structure corresponds to the difference between the sovereign yields with a remaining maturity of 10 and 2 years.

Table 8: Bank stock returns and monetary policy surprises

\begin{tabular}{|c|c|c|c|c|}
\hline & \multicolumn{2}{|c|}{ Stock returns } & \multicolumn{2}{|c|}{ CDS spreads } \\
\hline & (1) & (2) & (4) & (5) \\
\hline Short-term rate surprises ${ }_{t}$ & $\begin{array}{c}-12.52^{* * *} \\
(2.106)\end{array}$ & $\begin{array}{c}-14.85^{* * *} \\
(2.336)\end{array}$ & $\begin{array}{l}-0.0184 \\
(0.0647)\end{array}$ & $\begin{array}{c}0.0714 \\
(0.0731)\end{array}$ \\
\hline Slope surprises $_{j, t}$ & $\begin{array}{l}-0.832 \\
(0.775)\end{array}$ & $\begin{array}{c}-1.423^{*} \\
(0.708)\end{array}$ & $\begin{array}{l}0.124 * * \\
(0.0548)\end{array}$ & $\begin{array}{l}0.133 * * \\
(0.0574)\end{array}$ \\
\hline NPL ratio ${ }_{i, j, \tau}$ & $\begin{array}{c}-0.339 * * \\
(0.135)\end{array}$ & $\begin{array}{c}-0.312^{* *} \\
(0.141)\end{array}$ & $\begin{array}{c}0.0247^{* * *} \\
(0.00858)\end{array}$ & $\begin{array}{c}0.0247 * * * \\
(0.00869)\end{array}$ \\
\hline Regulatory capital ratio ${ }_{i, j}, \tau$ & $\begin{array}{c}-0.309 * * \\
(0.124)\end{array}$ & $\begin{array}{c}-0.343^{* *} \\
(0.144)\end{array}$ & $\begin{array}{c}0.0105^{*} \\
(0.00614)\end{array}$ & $\begin{array}{c}0.0138^{*} \\
(0.00735)\end{array}$ \\
\hline Cost-to-income ratio ${ }_{i j, \tau}$ & $\begin{array}{c}0.0140 \\
(0.0292)\end{array}$ & $\begin{array}{c}0.0132 \\
(0.0292)\end{array}$ & $\begin{array}{c}-0.00417^{* * *} \\
(0.00153)\end{array}$ & $\begin{array}{c}-0.00424^{* *} \\
(0.00159)\end{array}$ \\
\hline$\left(\right.$ Short-term rate $\left._{t}\right) \times($ NPL ratio $i j, \tau)$ & & $\begin{array}{c}0.452 \\
(0.899)\end{array}$ & & $\begin{array}{l}-0.00901 \\
(0.0109)\end{array}$ \\
\hline$\left(\right.$ Slope $\left._{t}\right) \times\left(\right.$ NPL ratio $\left._{i j, \tau}\right)$ & & $\begin{array}{c}-0.387^{* *} \\
(0.163)\end{array}$ & & $\begin{array}{c}0.0000636 \\
(0.00240)\end{array}$ \\
\hline$\left(\right.$ Short-term rate $\left._{t}\right) \times$ (Regulatory capital ratio $\left.i j, \tau\right)$ & & $\begin{array}{c}3.670^{* * *} \\
(1.065)\end{array}$ & & $\begin{array}{l}-0.0534 \\
(0.0412)\end{array}$ \\
\hline$\left(\right.$ Slope $\left._{t}\right) \times$ (Regulatory capital ratio $\left.{ }_{i j, \tau}\right)$ & & $\begin{array}{l}-0.170 \\
(0.356)\end{array}$ & & $\begin{array}{c}-0.0125 \\
(0.00990)\end{array}$ \\
\hline Bank FE & Yes & Yes & Yes & Yes \\
\hline Number of observations & 567 & 567 & 615 & 615 \\
\hline$\underline{\mathrm{R}}^{2}$ & 0.138 & 0.161 & 0.197 & 0.202 \\
\hline
\end{tabular}

Note: Dependent variable in each regression is one-day bank stock return (column 1 and 2) or change in CDS spread (column 3 and 4) on the ECB Governing Council announcement date t. Surprises for short-term rates, country-specific slope, euro area slope, and sovereign spread are derived from an event study using a 2-day window around policy announcements, also controlling for the surprise component of a large set of macroeconomic releases. Bank-specific controls are measured as of the end of the year preceding each monetary policy announcement. Standard errors clustered at bank level in parentheses: $* \mathrm{p}<.1, * * \mathrm{p}<.05$, *** $\mathrm{p}<.01$. 
Monetary policy surprises are derived from an event study using a 2-day window around policy announcements, also controlling for the surprise component of a large set of macroeconomic releases (as shown in equation 4). The vector Controls $_{i, j, \tau}$ comprises a set of indicators of bank balance sheet characteristics as of the end of the year preceding each monetary policy announcement, indicated by $\tau$.

The results reported in Table 8 indicate that monetary policy easing shocks, as measured by surprises on both the level (short-term rate) and (country-specific) slope of the yield curve, tend to have a positive impact on banks' market valuations. An unexpected decrease of ten basis points in the short-term rate - with no surprise change in the slope of the yield curve - causes the median bank's stock price to increase by about $1.5 \%$ (column 1); a shock to the country-specific slope of the yield curve of the same magnitude is estimated to increase the bank's stock price by about $0.15 \%$. Table 8 also shows that a monetary policy surprise flattening the term structure reduces bank CDS spreads, i.e. market participants' perception of bank credit risk. Finally, results in the last column of Table 8 show that the market assessment of the impact of monetary policy easing on banks' CDS changes is independent of bank asset quality and regulatory capital. In other words, the CDS of banks with higher NPLs or lower regulatory capital do not increase following monetary policy easing surprises. Overall, the results presented in Table 8 support those shown in Figures 8 and 9 above, suggesting that non-standard monetary policy easing tends to be viewed as positive both by banks' shareholders and debtholders.

\section{Conclusions}

In this paper, we have analysed the implications of alternative monetary policy actions on bank profitability and on market-based measures of bank shareholder value and bank risk. We analyse the euro area, which provides an interesting case study as it includes substantial bank and country heterogeneity within a monetary union where a broad set of unconventional policies, including negative interest rates, credit and quantitative easing have been implemented. Moreover, we exploit proprietary ECB data on individual bank balance sheets since 2007, and data from commercial providers since the creation of the euro area. We have tackled our question by analysing a micro and a macro econometric model, different types of data - ranging from the daily frequency of the event study to the quarterly frequency of the bank balance sheet indicators - and over different sample periods.

The results suggest some robust findings. First, monetary policy easing, summarised as either a decrease in short-term interest rates or a flattening of the yield curve, is only associated with lower bank profits if there are no appropriate controls for the endogeneity of monetary policy to bank 
financial health - especially during the crisis period - as well as to current and expected aggregate economic and financial conditions.

Second evidence from both a panel data model that uses individual bank balance sheet data and a dynamic macro model that uses more aggregate data, suggest that following a monetary policy shock, the various components of bank profitability react asymmetrically. More specifically, since the impact on loan loss provisions largely offsets the one on net interest income, the overall effects of monetary policy on bank profitability are muted. Importantly, our analysis suggests that keeping interest rates low for long might have negative consequences for bank profitability. However, our results suggest that it takes a long period of time for monetary policy to exert a substantial adverse effect on bank profitability as a result of looser policies, as accommodative monetary conditions support real economic activity which, in turn, has a positive impact on bank profitability, thereby offsetting the adverse impact. Moreover, policy easing tends to be more beneficial in relative terms for more efficient banks and for banks with lower asset quality. At the same time, banks engaging more extensively in maturity transformation activities tend to have a more positive reaction to a steepening of the yield curve.

Finally, market-based expectations on future bank profitability are analysed looking at the highfrequency changes in bank stock returns around monetary policy announcement dates. Financial market evidence suggests that both bank debtholders and shareholders tend to be better off when the central bank announces new, accommodative monetary policy. This is important not only for financial stability and systemic risk but also for the possible distributional consequences that these policies may have on bank shareholders and debtholders, including depositors. Though our results show that monetary policy easing does not hamper bank profitability, shareholder and bond-holder values, there could be distortionary effects possibly related to excessive bank risk-taking Jiménez et al, 2014; Ioannidou, Ongena and Peydró, 2015) and zombie lending/loan ever-greening practices (Freixas, Laeven and Peydró, 2015). Our analysis does not rule out these distortions at least to the extent that they are not immediately priced in by market participants. 


\section{References}

Admati, A. and Hellwig, M. (2014), The Bankers' New Clothes: What's Wrong with Banking and What to Do About it, Princeton University Press, Princeton, NJ.

Alessandri, P. and Nelson, B.D. (2015), Simple Banking: Profitability and the Yield Curve, Journal of Money, Credit and Banking, Vol. 47, Issue 1, pp. 143-175, 02.

Allen, F. and Rogoff, K. (2011), Asset prices, financial stability and monetary policy, in Jansson, P. and Persson, M. (eds.), The Riksbank's inquiry into the risks in the Swedish housing market, Sveriges Riksbank, Stockholm, pp. 189-218.

Allen, F., Carletti E. and Gale D. (2009), Interbank Market Liquidity and Central Bank Intervention, Journal of Monetary Economics, Vol. 56, Issue 5, pp. 639-652.

Allen, F., Carletti E. and Gale D. (2014), Money, Financial Stability and Efficiency, Journal of Economic Theory, Vol. 149, pp. 100-127.

Altavilla, C., Canova, F. and Ciccarelli, M. (2016), Mending the broken link: heterogeneous bank lending and monetary policy pass-through, Working Paper Series No 1978, European Central Bank.

Altavilla C., Carboni G., Motto R. (2015): Asset Purchase Programmes and Financial Markets: evidence from the Euro Area, Working Paper Series No 1864, European Central Bank

Altavilla, C. and Giannone, D. (2017), The Effectiveness of Non-Standard Monetary Policy Measures: Evidence from Survey Data, Journal of Applied Econometrics, vol. 32 (5), pages 952-964.

Angrist, J. D., Pischke, J.-S. (2009), Mostly Harmless Econometrics: An Empiricist's Companion, Princeton: Princeton University Press.

Athanasoglou, P.P., Brissimis, S.N., Delis, M.D. (2008), Bank-specific, industry-specific and macroeconomic determinants of bank profitability. Journal of International Financial Markets, Institutions \& Money 18 (2), 121-136

Begenau, J., Piazzesi, M. and Schneider, M. (2015), Banks' Risk Exposures, NBER Working Paper No 21334, National Bureau of Economic Research.

Bernanke, B.S. and Blinder, A.S. (1988), Credit, Money, and Aggregate Demand, The American Economic Review, Vol. 78, No 2, pp. 435-439.

Bernanke, B.S. and Blinder, A.S. (1992), The Federal Funds Rate and the Channels of Monetary Transmission, The American Economic Review, Vol. 82, No 4, pp. 901-921.

Bernanke, B.S. and Gertler, M. (1995), Inside the Black Box: The Credit Channel of Monetary Policy Transmission, Journal of Economic Perspectives, Vol. 9, No 4, pp. 27-48.

Bernanke, B.S. (2007), speech at The Credit Channel of Monetary Policy in the Twenty-first Century Conference, Federal Reserve Bank of Atlanta, Atlanta, Georgia.

Bernanke, B.S. and Kuttner, K.N. (2005), What Explains the Stock Market's Reaction to Federal Reserve Policy?, The Journal of Finance, Vol. 60, No 3, pp. 1221-1257. 
Borio C, Gambacorta L, Hofmann B. (2017), The influence of monetary policy on bank profitability, International Finance, 20:48-63.

Bourke, P. (1989), Concentration and other determinants of bank profitability in Europe, North America and Australia, Journal of Banking \& Finance, Vol. 13, Issue 1, pp. 65-79.

Brunnermeier, M.K., and Koby Y. (2017), The Reversal Interest Rate: The Effective Lower Bound of Monetary Policy, mimeo, version July 10, 2017.

Caballero, R.J., Takeo H., and Kashyap A.K. (2008), Zombie Lending and Depressed Restructuring in Japan, American Economic Review, 98(5): 1943-77.

Claessens, S., Coleman, N. and Donnelly, M. (2017), 'Low-For-Long' Interest Rates and Banks' Interest Margins and Profitability: Cross-Country Evidence, CEPR Discussion Paper No 11842.

De Mol, C., Giannone, D. and Reichlin, L. (2008), Forecasting using a large number of predictors: Is Bayesian shrinkage a valid alternative to principal components?, Journal of Econometrics, Vol. 146(2), pp. 318-328.

Diamond, D. and Rajan, R. (2006), Money in a Theory of Banking, The American Economic Review, Vol. 96, No 1, pp. 30-53.

Doan, T., Litterman R. and Sims C. A. (1984), Forecasting and conditional projection using realistic prior distributions, Econometric Reviews, 3, 1-100.

Ehrmann, M. and Fratzscher, M. (2004), Taking Stock: Monetary Policy Transmission to Equity Markets, ECB Working Paper No. 354.

English, W.B., Van den Heuvel, S.J. and Zakrajsek E. (2014), Interest Rate Risk and Bank Equity Valuations, Working Paper Series 14-05, Wharton Financial Institutions Center.

Flannery, M.J. (1981), Market Interest Rates and Commercial Bank Profitability: An Empirical Investigation, Journal of Finance, Vol. 36, pp. 1085-1101.

Flannery, M.J. (1983), Interest Rates and Bank Profitability: Additional Evidence, Journal of Money, Credit and Banking, Vol. 15, Issue 3, pp. 355-362.

Freixas, X. and Jorge, J. (2008), The Role of Interbank Markets in Monetary Policy: A Model with Rationing, Journal of Money, Credit and Banking, Vol. 40, No 6, pp. 1151-1176.

Freixas, X., Laeven, L. and Peydrò, J-L (2015), Systemic Risk, Crises, and Macroprudential Regulation, MIT Press, Cambridge, MA.

Freixas, X., Martin, A. and Skeie, D. (2011), Bank Liquidity, Interbank Markets, and Monetary Policy, The Review of Financial Studies, Vol. 24, Issue 8, pp. 2656-2692.

Freixas, X. and Rochet J.-C. (2008), Microeconomics of Banking, MIT Press, Cambridge, MA.

Garcia-Herrero, A., Gavila, S., Santabarbara, D. (2009), What explains the low profitability of Chinese banks?, Journal of Banking and Finance 33 (1), 2080-2092. 
Gertler, M. and Kiyotaki, N. (2010), Financial Intermediation and Credit Policy in Business Cycle Analysis, in Friedman B.M. and Woodford, M. (eds.), Handbook of Monetary Economics, vol.3, pp.547599.

Gertler, M. and Karadi, P. (2011), A Model of Unconventional Monetary Policy, Journal of Monetary Economics, Vol. 58, Issue 1, pp. 17-34.

Gertler, M. and Karadi, P. (2013), QE 1 vs. 2 vs. 3. . . : A Framework for Analyzing Large-Scale Asset Purchases as a Monetary Policy Tool, International Journal of Central Banking, IJCB, Vol. 9, No 1, pp. 5-53.

Giannone, D., Lenza, M. and Primiceri, G. (2015), Priors for Vector Autoregressions, Review of Economics and Statistics, Vol. 2(97), pp. 436-451.

Gürkaynak, R.S. and Wright, J.H. (2013), Identification and Inference Using Event Studies, CEPR Discussion Papers No 9388.

Gürkaynak, R.S., Sack, B. and Swanson, E. (2005a), "The Sensitivity of Long-Term Interest Rates to Economic News: Evidence and Implications for Macroeconomic Models", The American Economic Review, Vol. 95, No 1, pp. 425-436.

Gürkaynak, R.S., Sack, B. and Swanson, E. (2005b), Do Actions Speak Louder Than Words? The Response of Asset Prices to Monetary Policy Actions and Statements, International Journal of Central Banking, 1 (1) (2005), pp. 55-92 .

Hancock, D. (1985), Bank Profitability, Interest Rates, and Monetary Policy, Journal of Money, Credit and Banking, Vol. 17, pp. 189-202.

Hoffmann P., Langfield S., Pierobon F., Vuillemey G. (2017), Who bears interest rate risk?, mimeo.

Ioannidou, V., Ongena, S., Peydró, J.-L. (2015), Monetary Policy, Risk-Taking, and Pricing: Evidence from a Quasi-Natural Experiment. Review of Finance 19 (1), 95-144.

Iyer R., J-L Peydró, da-Rocha-Lopes, S., Schoar A. (2014), Interbank Liquidity Crunch and the Firm Credit Crunch: Evidence from the 2007-2009 Crisis, Review of Financial Studies, 2014, vol. 27 (pg. 347-372).

Jiménez, G., Ongena, S., Peydró, J-L and Saurina, J. (2012), Credit Supply and Monetary Policy: Identifying the Bank Balance-Sheet Channel with Loan Applications, The American Economic Review, Vol. 102, No 5, pp. 2301-2326.

Jiménez, G., Ongena, S., Peydró, J-L and Saurina, J. (2014), Hazardous Times for Monetary Policy: What Do Twenty-Three Million Bank Loans Say about the Effects of Monetary Policy on Credit Risk-Taking?, Econometrica, Vol. 82, Issue 2, pp. 463-505. 
Jiménez, G., Ongena, S., Peydró, J-L and Saurina, J. (2017), Macroprudential Policy, Countercyclical Bank Capital Buffers and Credit Supply: Evidence from the Spanish Dynamic Provisioning Experiments, Journal of Political Economy, forthcoming.

Kashyap, A. and Stein, J. (2000), What Do a Million Observations on Banks Say about the Transmission of Monetary Policy?, The American Economic Review, Vol. 90, No 3, pp. 407-428.

Kiyotaki, N. and Moore, J. (2012), Liquidity, Business Cycles, and Monetary Policy, NBER Working Paper No 17934, National Bureau of Economic Research.

Litterman, R. B. (1979), Techniques of forecasting using vector autoregressions, Federal Reserve Bank of Minneapolis Working Paper No.115.

Nickell, S. (1981), Biases in Dynamic Models with Fixed Effects, Econometrica, Vol. 49, Issue 6, pp. $1417-1426$.

Praet, P. (2016), Monetary policy and the euro area banking system, speech by Peter Praet, Member of the Executive Board of the ECB, Madrid, 4 October.

Rajan, R. (2005), Has finance made the world riskier?, speech presented at Jackson Hole, Federal Reserve Bank, Federal Reserve Bank, August.

Rigobon, R. and Sack, B. (2004), The impact of monetary policy on asset prices, Journal of Monetary Economics, 51(8):1553-1575.

Saunders, A. and Schumacher, L. (2000), The Determinants of Bank Interest Rate Margins: An International Study, Journal of International Money \& Finance, Vol. 19 (6), pp. 813-832.

Sims, C. A. (1993), A Nine-Variable Probabilistic Macroeconomic Forecasting Model, Business Cycles, Indicators and Forecasting, NBER Chapters, pp. 179-212.

Stiglitz, J. (2016), The Theory of Credit and Macro-economic Stability, NBER Working Paper No 22837, National Bureau of Economic Research.

Stein, J.C. (2012), Monetary Policy as Financial Stability Regulation, The Quarterly Journal of Economics, Vol. 127, Issue 1, pp. 57-95.

Stein, J.C. (2014), Incorporating Financial Stability Considerations into a Monetary Policy Framework, speech given at the International Research Forum on Monetary Policy, Washington, D.C., 21 March, and at the International Monetary Fund 2014 Spring Meetings.

Taylor, J. (2008), The financial crisis and the policy responses: an empirical analysis of what went wrong, NBER Working Paper No 14631, National Bureau of Economic Research.

Thorbecke, W. (1997), On Stock Market Returns and Monetary Policy, Journal of Finance, Vol. 52, Issue 2, pp. 635-654. 


\section{Appendix 1 - Data}

This appendix presents some additional data on bank balance sheets in greater detail.

There is significant heterogeneity across countries in the loans that are set to reprice in the next 12 months. Short-term loans account for more than $75 \%$ of the total in Italy and Spain, and no more than 15\% in Germany and France. For the euro area, the share of loans that are set to reprice in the next 12 months is lower, at just below $40 \%$. For non-financial corporations, more than half of the stock of loans is set to reprice in the next 12 months, also reflecting the significant role of overdrafts. The share of short-term non-financial corporation loans is also relatively smaller in Germany and France than in Italy and Spain, even though the difference is less pronounced than for household loans (see Figure A1.1).

The importance of the impact of monetary policy action on bank profitability from capital gains depends on the structure of bank balance sheets. Monetary policy easing leads to an increase in the market value of debt securities and equity and, as holders of these securities, banks benefit from the associated capital gains. As shown in Figure A1.2, a significant share of euro area bank assets consists of securities and, in particular, government bonds.

The assessment of monetary policy-related capital gains depends not only on the class of security (i.e. equity/debt securities and corporate/government bonds) but also on the maturity and accounting portfolio of securities held by banks (see Figure A1.3). For the same change in yield, changes in valuation are higher the longer the maturity. Moreover, while changes in the valuation of securities carried at market value have a direct impact on the profit and loss account, securities included in the other accounting portfolios only generate capital gains if they are sold.

Figure A1.4 illustrates the measures of low-for-long used in Table 3. The left panel shows the distribution of the low-for-long measure obtained by counting the number of consecutive quarters in which residuals of a forward-looking Taylor rule are negative. The right panel reports two alternative measures of low-for-long obtained by counting the number of consecutive quarters in which the MRO and EONIA rates are below $1.5 \%$ and $1.25 \%$, respectively. 
Figure A1.1: Breakdown of loans by original maturity or time to interest rate reset (percentages)

Loans to households

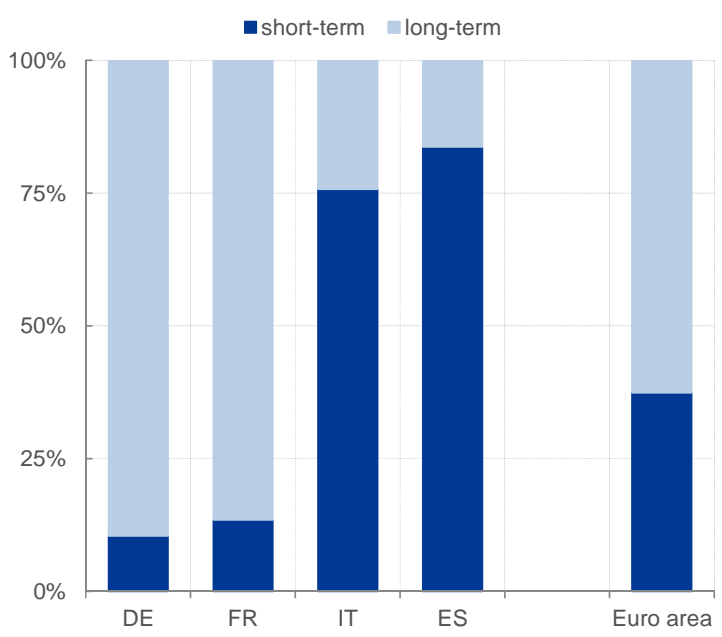

Loans to non-financial corporations

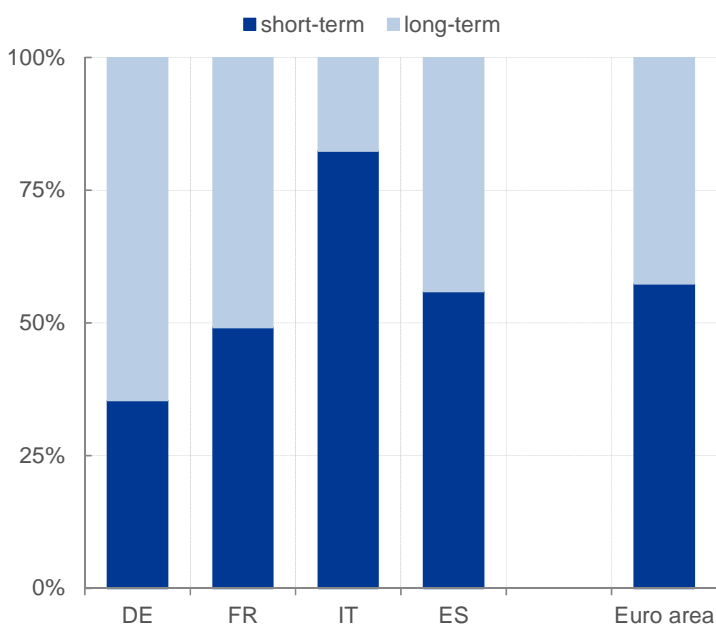

Note: Breakdown as of December 2016. Based on outstanding amounts of loan volumes. Shortterm refers to loans with original maturity up to one year and overdrafts plus loans with a remaining maturity over one year and interest rate reset within the next 12 months.

Figure A1.2: Breakdown of securities held, as a percentage of total assets

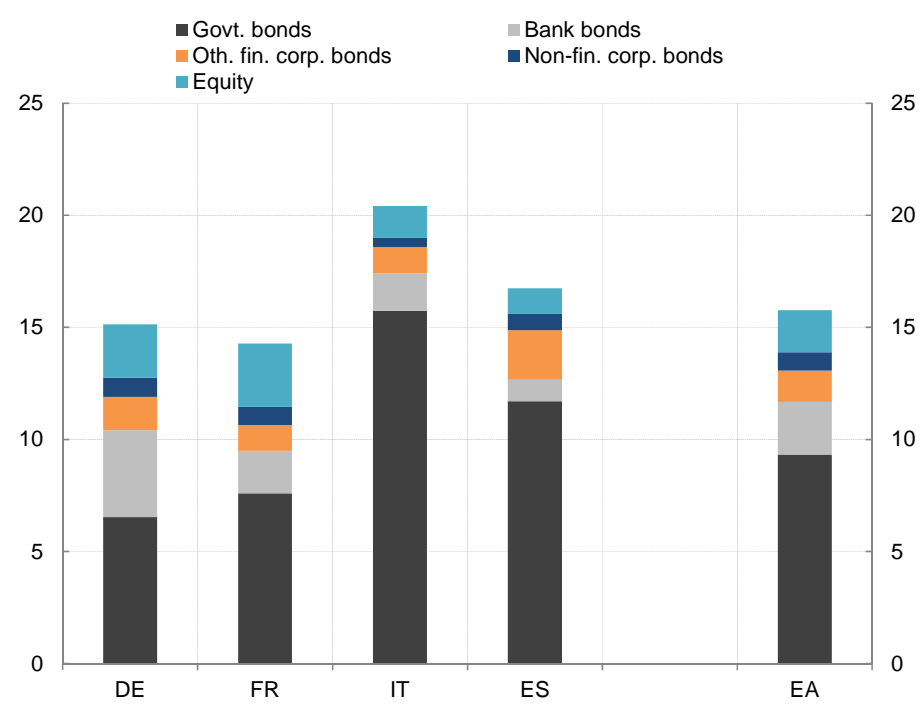

Note: Data on a consolidated basis for 339 euro area banking groups as of December 2016. 
Figure A1.3: Characteristics of securities held by euro area banks, on a consolidated basis

Distribution by accounting portfolio

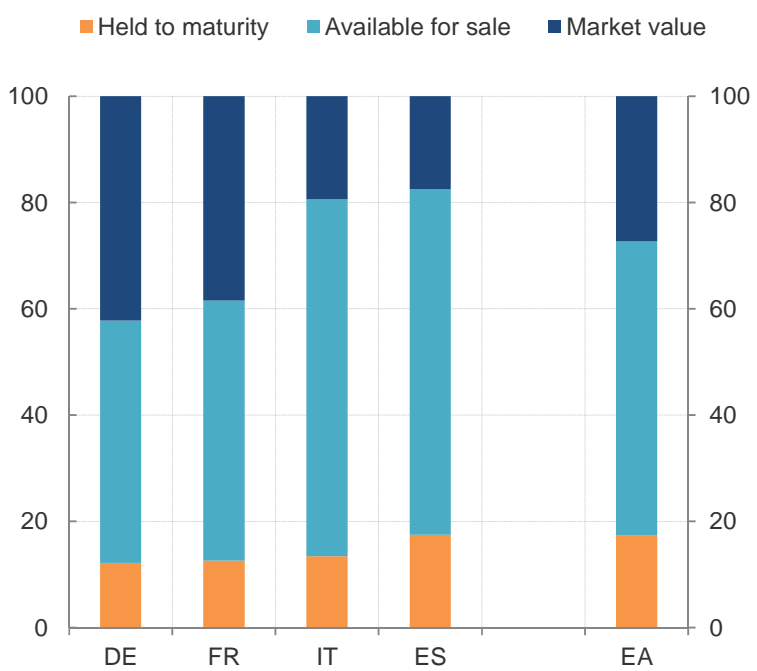

Distribution by residual maturity

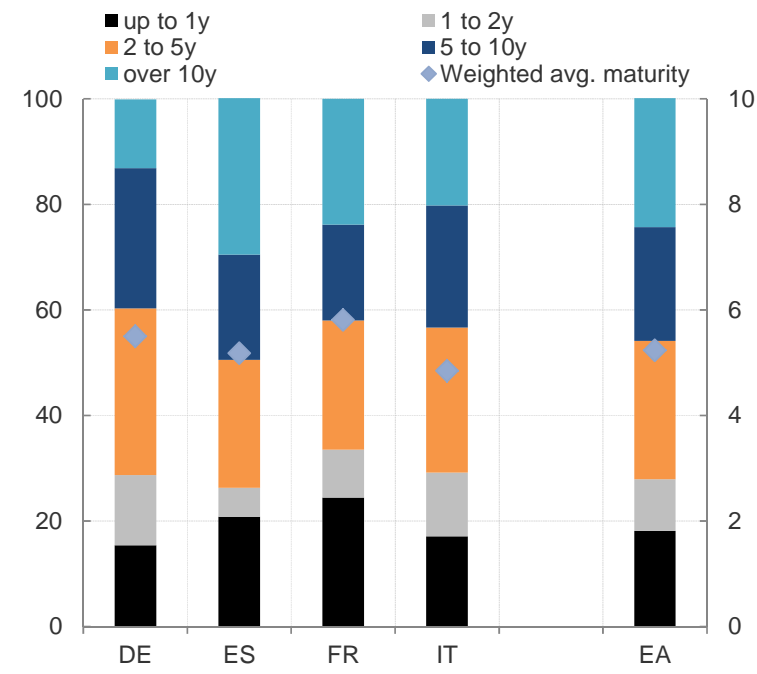

Notes: Data on a consolidated basis for 339 euro area banking groups as of December 2016.

Figure A1.4: Measures of low for long
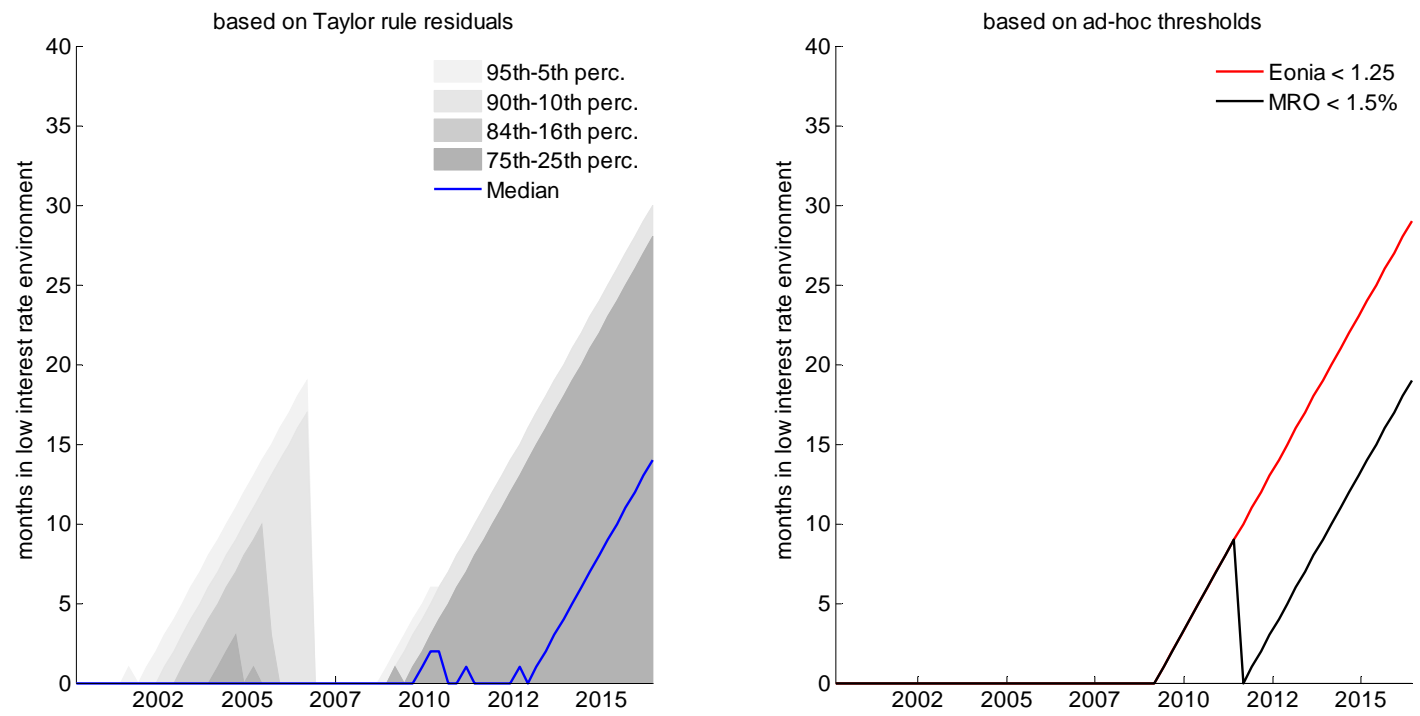

Note: the chart shows the measures of low-for-long used in Table 3. The left panel illustrated the distribution of the low-for-long measure obtained by counting the number of consecutive quarters in which residuals of a forward-looking Taylor rule are negative. The right panel reports two alternative measures of low-for-long obtained by counting the number of consecutive quarters in which the MRO and EONIA rates are below $1.5 \%$ and $1.25 \%$, respectively. 


\section{Appendix 2 - Robustness}

This appendix presents additional analysis carried out to check the robustness of the results presented in the main part of the paper.

Tables A2.1 and A2.2 replicate the results reported in Table 2 and Table 6, respectively, constraining the sample used in the estimation to be constant across all specifications. The results show that differences in the estimates across specifications are indeed driven by the additional information included in the model via controls variables and not by differences in the number of observations, which reflects differences in data availability across variables.

Table A2.3 shows that the results in Table 6 are robust to the use of the sample of banks defined in Table 2.

In the analysis presented in the main text, the slope of the yield curve is obtained by using the country-specific sovereign yield curve:, a bank faces a different yield curve constellation depending on the country where it operates. In order to test whether the results change when all the banks face a similar yield curve, we derive the slope of the term structure from the OIS rates (Table A2.4). Specifically, in order to test whether it is indeed the euro area yield curve that matters for bank profitability, we compare the results obtained from the baseline specification (column 1 in Table A2.4) with those obtained using the slope derived from the OIS curve (column 2, denoted with "euro area slope"). The coefficient is not significant. Finally, we check the importance of the sovereign spread (column 3) and find a negative and statistically significant coefficient: a reduction in the difference between the sovereign yields and the OIS rate at 10-year maturity is associated with an increase in profitability.

In addition, we show below that the results reported in the paper are robust to the omission of the fixed effects (Table A2.5) and to GMM estimation (Table A2.6).

Finally, Table A2.7 replicates the analysis on the profitability components reported in Table 4 for the shorter sample. Comparing the two tables indicates that when focusing on a shorter sample period the results obtained in the main text of the paper remain unchanged. 
Table A2.1: Robustness - keeping a fixed number of observations

\begin{tabular}{|c|c|c|c|c|c|c|}
\hline & (1) & (2) & (3) & (4) & (5) & (6) \\
\hline$\overline{\mathrm{ROA}_{i, j-1-1}}$ & $\begin{array}{l}0.520 * * * \\
(0.0554)\end{array}$ & $\begin{array}{l}0.501 * * * \\
(0.0523)\end{array}$ & $\begin{array}{c}0.469 * * * \\
(0.0516)\end{array}$ & $\begin{array}{c}0.456^{* * *} \\
(0.0561)\end{array}$ & $\begin{array}{c}0.411^{* * *} \\
(0.0588)\end{array}$ & $\begin{array}{c}0.454^{* * *} \\
(0.130)\end{array}$ \\
\hline Short-term rate ${ }_{t}$ & $\begin{array}{c}0.0575^{* * *} \\
(0.0111)\end{array}$ & $\begin{array}{c}0.0394 * * * \\
(0.0128)\end{array}$ & $\begin{array}{c}0.0145 \\
(0.0129)\end{array}$ & $\begin{array}{l}0.00376 \\
(0.0137)\end{array}$ & $\begin{array}{l}0.00336 \\
(0.0150)\end{array}$ & \\
\hline Slope $_{j, t}$ & $\begin{array}{c}0.00463^{* * *} \\
(0.00164)\end{array}$ & $\begin{array}{c}0.00394^{* *} \\
(0.00160)\end{array}$ & $\begin{array}{c}0.00311^{* *} \\
(0.00155)\end{array}$ & $\begin{array}{c}0.00115 \\
(0.00130)\end{array}$ & $\begin{array}{c}0.00152 \\
(0.00154)\end{array}$ & \\
\hline VIX $_{t}$ & & $\begin{array}{c}-0.00412^{* * *} \\
(0.00144)\end{array}$ & $\begin{array}{c}0.00137 \\
(0.00159)\end{array}$ & $\begin{array}{c}0.00241 \\
(0.00185)\end{array}$ & $\begin{array}{c}0.00207 \\
(0.00204)\end{array}$ & \\
\hline Real GDP growth ${ }_{j, t}$ & & $\begin{array}{l}0.0196 * * \\
(0.00815)\end{array}$ & $\begin{array}{l}-0.00376 \\
(0.00831)\end{array}$ & $\begin{array}{l}-0.00683 \\
(0.00891)\end{array}$ & $\begin{array}{l}-0.00184 \\
(0.00927)\end{array}$ & \\
\hline Inflation $_{j, t}$ & & $\begin{array}{c}0.0434 \\
(0.0313)\end{array}$ & $\begin{array}{c}0.0421 \\
(0.0373)\end{array}$ & $\begin{array}{c}0.0386 \\
(0.0391)\end{array}$ & $\begin{array}{l}0.0370 \\
(0.0401)\end{array}$ & \\
\hline Expected real GDP growth ${ }_{j, t}$ & & & $\begin{array}{c}0.133^{* * *} \\
(0.0216)\end{array}$ & $\begin{array}{c}0.110^{* * *} \\
(0.0186)\end{array}$ & $\begin{array}{c}0.112 * * * \\
(0.0181)\end{array}$ & \\
\hline Expected inflation $_{j, t}$ & & & $\begin{array}{c}0.0894 \\
(0.0552)\end{array}$ & $\begin{array}{c}0.105^{*} \\
(0.0583)\end{array}$ & $\begin{array}{c}0.0808 \\
(0.0622)\end{array}$ & \\
\hline Expected default frequency $y_{j, t}$ & & & & $\begin{array}{c}-0.0644 * * \\
(0.0263)\end{array}$ & $\begin{array}{c}-0.0546^{* *} \\
(0.0258)\end{array}$ & \\
\hline NPL ratio $_{i, j, t-1}$ & & & & & $\begin{array}{c}-0.0104 * * * \\
(0.00394)\end{array}$ & $\begin{array}{c}0.000854 \\
(0.0141)\end{array}$ \\
\hline Regulatory capital ratio ${ }_{i, j, t-1}$ & & & & & $\begin{array}{c}0.00568 \\
(0.00378)\end{array}$ & $\begin{array}{c}0.0179 * * \\
(0.00780)\end{array}$ \\
\hline Cost-to-income ratio ${ }_{i, j, t-1}$ & & & & & $\begin{array}{c}-0.00319 * * \\
(0.00157)\end{array}$ & $\begin{array}{c}0.00230 \\
(0.00433)\end{array}$ \\
\hline 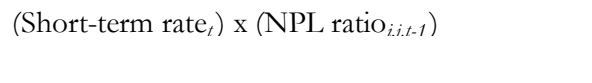 & & & & & & $\begin{array}{c}0.00575 \\
(0.00650)\end{array}$ \\
\hline 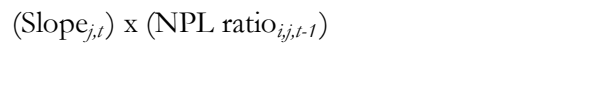 & & & & & & $\begin{array}{c}-0.00273^{* * *} \\
(0.000323)\end{array}$ \\
\hline$\left({\left.\text { Short-term } \text { rate }_{j, t}\right) \times(\text { Cost-to-income ratio }}_{i, j, t-1}\right)$ & & & & & & $\begin{array}{l}0.00296 * \\
(0.00174)\end{array}$ \\
\hline$\left(\right.$ Slope $\left._{j, t}\right) \times$ (Cost-to-income ratio $\left.{ }_{i, j, t-1}\right)$ & & & & & & $\begin{array}{c}0.000528^{* * *} \\
(0.0000838)\end{array}$ \\
\hline Bank FE & Yes & Yes & Yes & Yes & Yes & Yes \\
\hline Country*time FE & No & No & No & No & No & Yes \\
\hline Number of observations & 2974 & 2974 & 2974 & 2974 & 2974 & 2974 \\
\hline $\mathrm{R}^{2}$ & 0.574 & 0.582 & 0.597 & 0.601 & 0.605 & 0.771 \\
\hline
\end{tabular}

Note: The dependent variable is the return on assets (ROA). Data are at quarterly frequency covering an unbalanced sample of 288 banks for the period Q1 2000 - Q2 2016. Standard errors clustered at bank level in parentheses: * $\mathrm{p}<.1, * * \mathrm{p}<.05, * * * \mathrm{p}<.01$. 
Table A2.2: Robustness - keeping a fixed number of observations

\begin{tabular}{|c|c|c|c|c|c|c|}
\hline & (1) & (2) & (3) & (4) & (5) & (6) \\
\hline \multirow[t]{2}{*}{$\mathrm{ROA}_{i, j, t-1}$} & $0.0934 * *$ & $0.0845^{* *}$ & $0.0784^{* *}$ & $0.0679 *$ & -0.00141 & $0.0894 * *$ \\
\hline & $(0.0390)$ & $(0.0398)$ & $(0.0383)$ & $(0.0400)$ & $(0.0428)$ & $(0.0403)$ \\
\hline \multirow[t]{2}{*}{ Short-term rate ${ }_{t}$} & $0.0667 * *$ & 0.0547 & 0.0511 & 0.0352 & -0.0195 & \\
\hline & $(0.0310)$ & $(0.0343)$ & $(0.0353)$ & $(0.0349)$ & $(0.0254)$ & \\
\hline \multirow[t]{2}{*}{ Slope $_{j, t}$} & $0.00430^{* * *}$ & $0.00433 * * *$ & $0.00328 * *$ & 0.00123 & 0.000926 & \\
\hline & $(0.00125)$ & $(0.00127)$ & $(0.00132)$ & $(0.00166)$ & $(0.00148)$ & \\
\hline \multirow[t]{2}{*}{$\mathrm{VIX}_{t}$} & & -0.00321 & 0.00142 & 0.00187 & $-0.00654 * * *$ & \\
\hline & & $(0.00278)$ & $(0.00258)$ & $(0.00253)$ & $(0.00236)$ & \\
\hline \multirow[t]{2}{*}{ Real GDP growth grt } & & $0.0153^{* *}$ & -0.00439 & -0.00781 & $0.0119 *$ & \\
\hline & & $(0.00620)$ & $(0.00644)$ & $(0.00645)$ & $(0.00624)$ & \\
\hline \multirow[t]{2}{*}{ Inflation $_{j, t}$} & & -0.0315 & $0.0425^{*}$ & $0.0500 *$ & $0.0467^{*}$ & \\
\hline & & $(0.0257)$ & $(0.0254)$ & $(0.0258)$ & $(0.0263)$ & \\
\hline \multirow[t]{2}{*}{ Expected real GDP growth ${ }_{j, t}$} & & & $0.140 * * *$ & $0.115^{* * *}$ & $0.123^{* * *}$ & \\
\hline & & & $(0.0283)$ & $(0.0302)$ & $(0.0281)$ & \\
\hline \multirow[t]{2}{*}{ Expected inflation $_{j, t}$} & & & 0.0314 & 0.0402 & -0.0370 & \\
\hline & & & $(0.0534)$ & $(0.0553)$ & $(0.0531)$ & \\
\hline \multirow[t]{2}{*}{ Expected default frequency ${ }_{j, t}$} & & & & $-0.0814 * *$ & $-0.0691 *$ & \\
\hline & & & & $(0.0397)$ & $(0.0399)$ & \\
\hline \multirow[t]{2}{*}{$\mathrm{NPL}_{\text {ratio }}{ }_{i, j, t-1}$} & & & & & $-0.0471 * * *$ & $-0.0264 * *$ \\
\hline & & & & & $(0.0101)$ & $(0.0103)$ \\
\hline \multirow[t]{2}{*}{ Regulatory capital ratio $_{i, j, t-1}$} & & & & & -0.0135 & 0.00568 \\
\hline & & & & & $(0.00872)$ & $(0.0120)$ \\
\hline \multirow[t]{2}{*}{ Cost-to-income ratio ${ }_{i, j, t-1}$} & & & & & -0.00332 & -0.000971 \\
\hline & & & & & $(0.00243)$ & $(0.00181)$ \\
\hline \multirow[t]{2}{*}{ Liquid asset ratio ${ }_{i, j, t-1}$} & & & & & -0.00609 & -0.00163 \\
\hline & & & & & $(0.00543)$ & $(0.00507)$ \\
\hline \multirow[t]{2}{*}{ Maturity gap $_{i, j, t-1}$} & & & & & $0.00372 * *$ & $0.00418^{*}$ \\
\hline & & & & & $(0.00143)$ & $(0.00216)$ \\
\hline \multirow[t]{2}{*}{$\left(\right.$ Short-term rate $\left._{t}\right) \mathrm{x}\left(\right.$ Maturity gap $\left.\mathrm{p}_{i, j, t-1}\right)$} & & & & & & 0.000107 \\
\hline & & & & & & $(0.00159)$ \\
\hline \multirow[t]{2}{*}{$\left(\right.$ Slope $\left._{j, t}\right) \times\left(\right.$ Maturity gap $\left._{i, j, t-1}\right)$} & & & & & & $0.000696^{* *}$ \\
\hline & & & & & & $(0.000273)$ \\
\hline Bank FE & Yes & Yes & Yes & Yes & Yes & Yes \\
\hline Country*time FE & No & No & No & No & No & Yes \\
\hline Number of observations & 845 & 845 & 845 & 845 & 845 & 845 \\
\hline $\mathrm{R}^{2}$ & 0.398 & 0.399 & 0.427 & 0.432 & 0.467 & 0.646 \\
\hline
\end{tabular}

Note: The dependent variable is the return on assets (ROA). Data are at quarterly frequency covering an unbalanced sample of 234 banks for the period Q1 2007 - Q4 2016. Standard errors clustered at bank level in parentheses: ${ }^{*} \mathrm{p}<.1,{ }^{* *} \mathrm{p}<.05,{ }^{* * *} \mathrm{p}<.01$. 
Table A2.3: Results since Q4 2007 using the larger sample

\begin{tabular}{|c|c|c|c|c|c|c|c|}
\hline & (1) & (2) & (3) & (4) & (5) & (6) & (7) \\
\hline $\mathrm{ROA}_{i, j, t-1}$ & $\begin{array}{c}0.502 * * * \\
(0.0437)\end{array}$ & $\begin{array}{l}0.492^{* * *} \\
(0.0438)\end{array}$ & $\begin{array}{c}0.466 * * * \\
(0.0450)\end{array}$ & $\begin{array}{c}0.457^{* * * *} \\
(0.0486)\end{array}$ & $\begin{array}{c}0.434^{* * *} \\
(0.0594)\end{array}$ & $\begin{array}{c}0.395^{* * *} \\
(0.0612)\end{array}$ & $\begin{array}{c}0.440^{* * *} \\
(0.125)\end{array}$ \\
\hline Short-term rate ${ }_{t}$ & $\begin{array}{c}0.0264^{* * *} \\
(0.00756)\end{array}$ & $\begin{array}{c}0.0173 * * \\
(0.00816)\end{array}$ & $\begin{array}{c}0.00198 \\
(0.00800)\end{array}$ & $\begin{array}{l}-0.00796 \\
(0.00953)\end{array}$ & $\begin{array}{c}-0.00278 \\
(0.0148)\end{array}$ & $\begin{array}{c}-0.000345 \\
(0.0152)\end{array}$ & \\
\hline Slope $_{j, t}$ & $\begin{array}{c}0.00350^{* *} \\
(0.00138)\end{array}$ & $\begin{array}{c}0.00313^{* *} \\
(0.00138)\end{array}$ & $\begin{array}{c}0.00230 \\
(0.00141)\end{array}$ & $\begin{array}{l}0.000474 \\
(0.00144)\end{array}$ & $\begin{array}{r}0.00134 \\
(0.00131)\end{array}$ & $\begin{array}{c}0.00164 \\
(0.00152)\end{array}$ & \\
\hline $\mathrm{VIX}_{t}$ & & $\begin{array}{c}-0.00138^{*} \\
(0.000773)\end{array}$ & $\begin{array}{c}0.00356^{* * *} \\
(0.00113)\end{array}$ & $\begin{array}{c}0.00438^{* * *} \\
(0.00133)\end{array}$ & $\begin{array}{c}0.00387^{*} \\
(0.00201)\end{array}$ & $\begin{array}{c}0.00375 \\
(0.00230)\end{array}$ & \\
\hline Real GDP growth $_{j, t}$ & & $\begin{array}{c}0.0140^{* * *} \\
(0.00517)\end{array}$ & $\begin{array}{l}-0.00475 \\
(0.00525)\end{array}$ & $\begin{array}{l}-0.00754 \\
(0.00563)\end{array}$ & $\begin{array}{c}-0.00643 \\
(0.0102)\end{array}$ & $\begin{array}{c}-0.00314 \\
(0.0103)\end{array}$ & \\
\hline Inflation $_{j, t}$ & & $\begin{array}{c}0.0198 \\
(0.0195)\end{array}$ & $\begin{array}{c}0.0400 * \\
(0.0240)\end{array}$ & $\begin{array}{c}0.0351 \\
(0.0245)\end{array}$ & $\begin{array}{c}0.0299 \\
(0.0434)\end{array}$ & $\begin{array}{c}0.0325 \\
(0.0445)\end{array}$ & \\
\hline Expected real GDP growth $_{j, t}$ & & & $\begin{array}{c}0.113^{* * *} \\
(0.0171)\end{array}$ & $\begin{array}{c}0.0925^{* * *} \\
(0.0146)\end{array}$ & $\begin{array}{c}0.107^{* * *} \\
(0.0233)\end{array}$ & $\begin{array}{c}0.112^{* * *} \\
(0.0224)\end{array}$ & \\
\hline Expected inflation $_{j, t}$ & & & $\begin{array}{c}0.0517 \\
(0.0381)\end{array}$ & $\begin{array}{c}0.0677 \\
(0.0422)\end{array}$ & $\begin{array}{c}0.106 \\
(0.0648)\end{array}$ & $\begin{array}{c}0.0838 \\
(0.0676)\end{array}$ & \\
\hline Expected default frequency $_{j, t}$ & & & & $\begin{array}{c}-0.0600^{* *} \\
(0.0251)\end{array}$ & $\begin{array}{c}-0.0607 * * \\
(0.0293)\end{array}$ & $\begin{array}{c}-0.0510 * \\
(0.0292)\end{array}$ & \\
\hline NPL ratio $_{i, j, t-1}$ & & & & & & $\begin{array}{c}-0.00912^{* *} \\
(0.00421)\end{array}$ & $\begin{array}{l}-0.0123 \\
(0.0121)\end{array}$ \\
\hline Regulatory capital ratio ${ }_{i, j, t-1}$ & & & & & & $\begin{array}{c}0.00713^{*} \\
(0.00400)\end{array}$ & $\begin{array}{l}0.0170^{* *} \\
(0.00734)\end{array}$ \\
\hline Cost-to-income ratio $_{i, j, t-1}$ & & & & & & $\begin{array}{l}-0.00300 * \\
(0.00162)\end{array}$ & $\begin{array}{c}0.00153 \\
(0.00379)\end{array}$ \\
\hline$\left(\right.$ Short-term rate $\left._{t}\right) \times\left(\mathrm{NPL} \mathrm{ratio}_{\text {i.i.t-1 }}\right)$ & & & & & & & $\begin{array}{c}-0.000258 \\
(0.00435)\end{array}$ \\
\hline$\left(\right.$ Slope $\left._{j, t}\right) \times\left(\right.$ NPL $\left._{\text {ratio }}{ }_{i, j, t-1}\right)$ & & & & & & & $\begin{array}{c}-0.00286^{* * *} \\
(0.000332)\end{array}$ \\
\hline$\left({\left.\text { Short-term } \text { rate }_{j, t}\right) \times(\text { Cost-to-income ratio }}_{i, j, t-1}\right)$ & & & & & & & $\begin{array}{l}0.00266^{*} \\
(0.00136)\end{array}$ \\
\hline$\left(\right.$ Slope $\left._{j, t}\right) \times\left(\right.$ Cost-to-income ratio $\left.{ }_{i, j, t-1}\right)$ & & & & & & & $\begin{array}{c}0.000556^{* * *} \\
(0.0000890)\end{array}$ \\
\hline Bank FE & Yes & Yes & Yes & Yes & Yes & Yes & Yes \\
\hline Country*time FE & No & No & No & No & No & No & Yes \\
\hline Number of observations & 5637 & 5637 & 5637 & 5637 & 2806 & 2806 & 2806 \\
\hline $\mathrm{R}^{2}$ & 0.658 & 0.661 & 0.670 & 0.672 & 0.587 & 0.590 & 0.774 \\
\hline
\end{tabular}

Note: The dependent variable is the return on assets (ROA). Data are at quarterly frequency covering an unbalanced sample of 288 banks for the period Q1 2007 - Q2 2016. Standard errors clustered at bank level in parentheses: ${ }^{*} \mathrm{p}<.1,{ }^{* *} \mathrm{p}<.05,{ }^{* * *} \mathrm{p}<.01$. 
Table A2.4: Country-specific and euro area slope

\begin{tabular}{|c|c|c|c|}
\hline & (1) & (2) & (3) \\
\hline \multirow[t]{2}{*}{$\mathrm{ROA}_{i, j, t-1}$} & $0.409 * * *$ & $0.412^{* * *}$ & $0.397 * * *$ \\
\hline & $(0.0593)$ & $(0.0573)$ & $(0.0605)$ \\
\hline \multirow[t]{2}{*}{ Short-term rate $_{t}$} & 0.00375 & 0.00151 & 0.0128 \\
\hline & $(0.0151)$ & $(0.0149)$ & $(0.0129)$ \\
\hline \multirow[t]{2}{*}{ Country-specific slope $\mathrm{e}_{j, t}$} & 0.00142 & & \\
\hline & $(0.00152)$ & & \\
\hline \multirow[t]{2}{*}{ Euro area slope $_{t}$} & & 0.00464 & 0.0113 \\
\hline & & $(0.0251)$ & $(0.0245)$ \\
\hline \multirow[t]{2}{*}{ Sovereign spread $_{j, t}$} & & & $-0.0545^{* * *}$ \\
\hline & & & $(0.0174)$ \\
\hline \multirow[t]{2}{*}{ VIX $_{\mathrm{t}}$} & 0.00234 & 0.00248 & -0.000560 \\
\hline & $(0.00209)$ & $(0.00227)$ & $(0.00182)$ \\
\hline \multirow[t]{2}{*}{ Real GDP growth $_{j, t}$} & -0.00181 & -0.00209 & 0.00183 \\
\hline & $(0.00932)$ & $(0.00970)$ & $(0.00953)$ \\
\hline \multirow[t]{2}{*}{ Inflation $_{j, t}$} & 0.0335 & 0.0356 & 0.0298 \\
\hline & $(0.0420)$ & $(0.0413)$ & $(0.0422)$ \\
\hline \multirow[t]{2}{*}{ Expected real GDP growth $_{j, t}$} & $0.108^{* * *}$ & $0.106^{* * *}$ & $0.0738^{* * *}$ \\
\hline & $(0.0193)$ & $(0.0202)$ & $(0.0234)$ \\
\hline \multirow[t]{2}{*}{ Expected inflation $_{j, t}$} & 0.0841 & 0.0877 & 0.0836 \\
\hline & $(0.0633)$ & $(0.0649)$ & $(0.0594)$ \\
\hline \multirow[t]{2}{*}{ Expected default frequency $_{j, t}$} & $-0.0586^{* *}$ & $-0.0708^{* *}$ & 0.00522 \\
\hline & $(0.0277)$ & $(0.0319)$ & $(0.0213)$ \\
\hline \multirow[t]{2}{*}{ NPL ratio $i_{i, j, t-1}$} & $-0.00988^{* *}$ & $-0.00947^{* *}$ & $-0.0100^{* * *}$ \\
\hline & $(0.00396)$ & $(0.00404)$ & $(0.00363)$ \\
\hline \multirow[t]{2}{*}{ Regulatory capital ratio ${ }_{i j, t-1}$} & 0.00606 & 0.00608 & $0.00820^{* *}$ \\
\hline & $(0.00379)$ & $(0.00386)$ & $(0.00361)$ \\
\hline \multirow[t]{2}{*}{ Cost-to-income ratio ${ }_{i j, t-1}$} & $-0.00329 * *$ & $-0.00322 * *$ & $-0.00297 *$ \\
\hline & $(0.00158)$ & $(0.00155)$ & $(0.00153)$ \\
\hline Bank FE & Yes & Yes & Yes \\
\hline Number of observations & 2940 & 2940 & 2940 \\
\hline $\mathrm{R}^{2}$ & 0.603 & 0.602 & 0.609 \\
\hline
\end{tabular}

Note: The dependent variable is the return on assets (ROA). Data are at quarterly frequency covering an unbalanced sample of 288 banks for the period Q1 $2000-$ Q2 2016. Standard errors clustered at bank level in parentheses: ${ }^{*} \mathrm{p}<.1,{ }^{* *} \mathrm{p}<.05$, *** $\mathrm{p}<.01$. 
Table A2.5: Results without bank fixed effects

\begin{tabular}{|c|c|c|c|c|c|c|c|}
\hline & (1) & (2) & (3) & (4) & (5) & (6) & (7) \\
\hline $\mathrm{ROA}_{\mathrm{t}-1}$ & $\begin{array}{l}0.795^{* * *} \\
(0.0299)\end{array}$ & $\begin{array}{l}0.790^{* * *} \\
(0.0314)\end{array}$ & $\begin{array}{l}0.785^{* * *} \\
(0.0327)\end{array}$ & $\begin{array}{l}0.781 \text { *** } \\
(0.0333)\end{array}$ & $\begin{array}{l}0.658^{* * *} \\
(0.0431)\end{array}$ & $\begin{array}{l}0.603 * * * \\
(0.0484)\end{array}$ & $\begin{array}{c}0.650 * * * \\
(0.149)\end{array}$ \\
\hline Short-term rate $_{\mathrm{t}}$ & $\begin{array}{l}0.0105^{* *} \\
(0.00504)\end{array}$ & $\begin{array}{c}0.00147 \\
(0.00428)\end{array}$ & $\begin{array}{l}-0.00500 \\
(0.00447)\end{array}$ & $\begin{array}{c}-0.00862 * \\
(0.00491)\end{array}$ & $\begin{array}{l}-0.00890 \\
(0.0115)\end{array}$ & $\begin{array}{l}-0.0134 \\
(0.0153)\end{array}$ & \\
\hline Slope $_{t}$ & $\begin{array}{l}0.00179 * * \\
(0.000906)\end{array}$ & $\begin{array}{c}0.00141 \\
(0.000896)\end{array}$ & $\begin{array}{c}0.00120 \\
(0.000896)\end{array}$ & $\begin{array}{c}-0.000338 \\
(0.00123)\end{array}$ & $\begin{array}{c}0.00142 \\
(0.00109)\end{array}$ & $\begin{array}{c}0.00180 \\
(0.00126)\end{array}$ & \\
\hline VIX $_{t}$ & & $\begin{array}{c}-0.00286 * * * \\
(0.000654)\end{array}$ & $\begin{array}{l}-0.000986 \\
(0.000746)\end{array}$ & $\begin{array}{l}-0.000107 \\
(0.000869)\end{array}$ & $\begin{array}{c}0.0000682 \\
(0.00158)\end{array}$ & $\begin{array}{c}-0.000683 \\
(0.00159)\end{array}$ & \\
\hline Real GDP growth ${ }_{t}$ & & $\begin{array}{c}0.00832 * * \\
(0.00335)\end{array}$ & $\begin{array}{l}-0.00204 \\
(0.00294)\end{array}$ & $\begin{array}{c}-0.00497 * \\
(0.00272)\end{array}$ & $\begin{array}{l}-0.00969 \\
(0.00605)\end{array}$ & $\begin{array}{l}-0.00522 \\
(0.00637)\end{array}$ & \\
\hline Inflation $_{j, t}$ & & $\begin{array}{l}0.0226^{* *} \\
(0.0111)\end{array}$ & $\begin{array}{l}0.0223 \\
(0.0156)\end{array}$ & $\begin{array}{l}0.0279 * \\
(0.0145)\end{array}$ & $\begin{array}{l}0.0230 \\
(0.0328)\end{array}$ & $\begin{array}{l}0.0322 \\
(0.0334)\end{array}$ & \\
\hline Expected real GDP growth $_{t}$ & & & $\begin{array}{c}0.0514 * * * \\
(0.00973)\end{array}$ & $\begin{array}{c}0.0487 * * * \\
(0.00968)\end{array}$ & $\begin{array}{c}0.0857^{* * *} \\
(0.0172)\end{array}$ & $\begin{array}{c}0.0843 * * * \\
(0.0172)\end{array}$ & \\
\hline Expected inflation $_{\mathrm{t}}$ & & & $\begin{array}{l}0.00345 \\
(0.0283)\end{array}$ & $\begin{array}{l}0.00897 \\
(0.0297)\end{array}$ & $\begin{array}{c}0.0809 \\
(0.0557)\end{array}$ & $\begin{array}{c}0.0586 \\
(0.0569)\end{array}$ & \\
\hline Expected default frequency $y_{t}$ & & & & $\begin{array}{c}-0.0297 * * * \\
(0.00992)\end{array}$ & $\begin{array}{c}-0.0282^{* *} \\
(0.0129)\end{array}$ & $\begin{array}{l}-0.0207 \\
(0.0133)\end{array}$ & \\
\hline NPL ratio t-1 $_{1}$ & & & & & & $\begin{array}{c}-0.00787^{* * *} \\
(0.00226)\end{array}$ & $\begin{array}{c}-0.0495^{* * *} \\
(0.0163)\end{array}$ \\
\hline Regulatory capital ratio $\mathrm{t}_{\mathrm{t}-1}$ & & & & & & $\begin{array}{c}0.00163 \\
(0.00263)\end{array}$ & $\begin{array}{c}0.00461 \\
(0.00289)\end{array}$ \\
\hline Cost-to-income ratio ${ }_{\mathrm{t}-1}$ & & & & & & $\begin{array}{c}-0.00340^{* * *} \\
(0.00103)\end{array}$ & $\begin{array}{l}-0.000997 \\
(0.00279)\end{array}$ \\
\hline$\left(\right.$ Short-term rate $\left.{ }_{t}\right) \times\left(N P L\right.$ ratio $\left._{t-1}\right)$ & & & & & & & $\begin{array}{c}-0.0211 * * \\
(0.00839)\end{array}$ \\
\hline 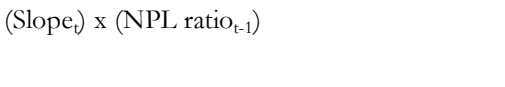 & & & & & & & $\begin{array}{c}-0.00147^{* * *} \\
(0.000262)\end{array}$ \\
\hline$\left(\right.$ Short-term rate $\left._{\mathrm{t}}\right) \times\left(\right.$ Cost-to-income ratio $\left.\mathrm{t}_{\mathrm{t}-1}\right)$ & & & & & & & $\begin{array}{c}0.00178 \\
(0.00140)\end{array}$ \\
\hline$\left(\right.$ Slope $\left._{t}\right) \times($ Cost-to-income ratio $t-1)$ & & & & & & & $\begin{array}{l}0.000193 * \\
(0.000107)\end{array}$ \\
\hline Bank FE & No & No & No & No & No & No & No \\
\hline Country*time FE & No & No & No & No & No & No & Yes \\
\hline Number of observations & 6768 & 6768 & 6768 & 6768 & 2974 & 2974 & 2974 \\
\hline $\mathrm{R}^{2}$ & 0.634 & 0.636 & 0.639 & 0.640 & 0.528 & 0.537 & 0.703 \\
\hline
\end{tabular}

Note: The dependent variable is the return on assets (ROA). Data are at quarterly frequency covering an unbalanced sample of 288 banks for the period Q1 $2000-$ Q2 2016. The constant is omitted in columns 1-3. Standard errors clustered at bank level in parentheses: ${ }^{*} \mathrm{p}<.1, * * \mathrm{p}<.05$, *** $\mathrm{p}<.01$. 
Table A2.6: GMM results for monetary policy and balance sheet characteristics

\begin{tabular}{|c|c|c|c|c|c|}
\hline & (1) & (2) & (3) & (4) & (5) \\
\hline $\mathrm{ROA}_{\mathrm{t}-1}$ & $\begin{array}{c}0.554 * * * \\
(0.0645)\end{array}$ & $\begin{array}{c}0.553^{* * *} \\
(0.0592)\end{array}$ & $\begin{array}{c}0.531 * * * \\
(0.0610)\end{array}$ & $\begin{array}{l}0.480 * * * \\
(0.0929)\end{array}$ & $\begin{array}{l}0.463^{* * *} \\
(0.0803)\end{array}$ \\
\hline Short-term rate ${ }_{t}$ & $\begin{array}{c}0.0265^{* * *} \\
(0.00905)\end{array}$ & $\begin{array}{c}0.0169 * \\
(0.00999)\end{array}$ & $\begin{array}{l}0.00900 \\
(0.0105)\end{array}$ & $\begin{array}{c}0.0233 \\
(0.0203)\end{array}$ & $\begin{array}{c}0.0362 \\
(0.0320)\end{array}$ \\
\hline Slope $_{t}$ & $\begin{array}{l}0.00412 * \\
(0.00211)\end{array}$ & $\begin{array}{l}0.00394 * \\
(0.00218)\end{array}$ & $\begin{array}{c}0.00223 \\
(0.00279)\end{array}$ & $\begin{array}{c}0.00312 \\
(0.00191)\end{array}$ & $\begin{array}{l}0.000563 \\
(0.00132)\end{array}$ \\
\hline $\mathrm{VIX}_{\mathrm{t}}$ & & $\begin{array}{c}-0.00323^{* * *} \\
(0.00113)\end{array}$ & $\begin{array}{l}0.000484 \\
(0.00152)\end{array}$ & $\begin{array}{c}0.00206 \\
(0.00206)\end{array}$ & $\begin{array}{c}0.00469 * * \\
(0.00229)\end{array}$ \\
\hline Real GDP growth $_{t}$ & & $\begin{array}{c}0.0103^{*} \\
(0.00596)\end{array}$ & $\begin{array}{l}-0.00640 \\
(0.00625)\end{array}$ & $\begin{array}{c}-0.0216^{* *} \\
(0.0104)\end{array}$ & $\begin{array}{l}-0.00665 \\
(0.00826)\end{array}$ \\
\hline Inflation $_{j, t}$ & & $\begin{array}{c}0.0260 \\
(0.0264)\end{array}$ & $\begin{array}{l}0.0500 * \\
(0.0257)\end{array}$ & $\begin{array}{c}0.0317 \\
(0.0522)\end{array}$ & $\begin{array}{c}0.0541 * \\
(0.0299)\end{array}$ \\
\hline Expected real GDP growth ${ }_{t}$ & & & $\begin{array}{c}0.0752^{* * *} \\
(0.0154)\end{array}$ & $\begin{array}{l}0.107^{* * *} \\
(0.0220)\end{array}$ & $\begin{array}{c}0.0679 * * * \\
(0.0169)\end{array}$ \\
\hline Expected inflation $_{\mathrm{t}}$ & & & $\begin{array}{l}-0.0158 \\
(0.0374)\end{array}$ & $\begin{array}{c}0.0521 \\
(0.0650)\end{array}$ & $\begin{array}{c}0.0539 \\
(0.0516)\end{array}$ \\
\hline Expected default frequency $y_{t}$ & & & $\begin{array}{l}-0.0332 \\
(0.0215)\end{array}$ & $\begin{array}{c}-0.0400^{*} \\
(0.0230)\end{array}$ & $\begin{array}{c}-0.0680^{* * *} \\
(0.0232)\end{array}$ \\
\hline NPL ratio $_{t-1}$ & & & & & $\begin{array}{l}-0.00164 \\
(0.00957)\end{array}$ \\
\hline Regulatory capital ratio ${ }_{\mathrm{t}-1}$ & & & & & $\begin{array}{c}0.0168 \\
(0.0169)\end{array}$ \\
\hline Cost-to-income ratio ${ }_{\mathrm{t}-1}$ & & & & & $\begin{array}{c}-0.00902 * \\
(0.00493)\end{array}$ \\
\hline Number of observations & 6768 & 6768 & 6768 & 2974 & 2990 \\
\hline $\operatorname{AR}(1)$ & 0.00000173 & 0.00000129 & 0.00000111 & 0.0000282 & 0.000297 \\
\hline $\operatorname{AR}(2)$ & 0.0710 & 0.0734 & 0.0648 & 0.0633 & 0.0545 \\
\hline
\end{tabular}

Note: The dependent variable is the return on assets (ROA). Data are at quarterly frequency covering an unbalanced sample of 288 banks for the period Q1 2000 - Q2 2016. The constant is omitted. Standard errors clustered at bank level in parentheses: ${ }^{*} \mathrm{p}<.1,{ }^{* *} \mathrm{p}<.05,{ }^{* * *} \mathrm{p}<.01$. 
Table A2.7: profitability components an monetary policy (restricted dataset)

\begin{tabular}{|c|c|c|c|c|}
\hline & $\begin{array}{l}(1) \\
\text { NII } \\
\end{array}$ & $\begin{array}{c}(2) \\
\text { NNI } \\
\end{array}$ & $\begin{array}{c}(3) \\
\text { PROV } \\
\end{array}$ & $\begin{array}{c}(4) \\
\mathrm{ROA} \\
\end{array}$ \\
\hline$Y_{i, j, t-1}$ & $\begin{array}{c}0.656 * * * \\
(0.0588)\end{array}$ & $\begin{array}{c}0.195^{* * *} \\
(0.0558)\end{array}$ & $\begin{array}{c}0.0384 \\
(0.0443)\end{array}$ & $\begin{array}{l}-0.00141 \\
(0.0428)\end{array}$ \\
\hline Short-term rate $_{t}$ & $\begin{array}{l}0.0101^{* * *} \\
(0.00378)\end{array}$ & $\begin{array}{l}-0.00820 \\
(0.00883)\end{array}$ & $\begin{array}{c}0.0114 \\
(0.00778)\end{array}$ & $\begin{array}{l}-0.0195 \\
(0.0254)\end{array}$ \\
\hline Slope $_{j, t}$ & $\begin{array}{c}-0.000112 \\
(0.0000890)\end{array}$ & $\begin{array}{c}0.000229 \\
(0.000272)\end{array}$ & $\begin{array}{c}0.000865^{* * *} \\
(0.000279)\end{array}$ & $\begin{array}{l}0.000926 \\
(0.00148)\end{array}$ \\
\hline VIX $_{t}$ & $\begin{array}{l}0.000106 \\
(0.000273)\end{array}$ & $\begin{array}{l}-0.00167^{* *} \\
(0.000734)\end{array}$ & $\begin{array}{l}-0.00158^{*} \\
(0.000819)\end{array}$ & $\begin{array}{c}-0.00654^{* * *} \\
(0.00236)\end{array}$ \\
\hline Real GDP growth ${ }_{j, t}$ & $\begin{array}{c}0.00134 * \\
(0.000746)\end{array}$ & $\begin{array}{r}-0.000149 \\
(0.00161)\end{array}$ & $\begin{array}{l}-0.000988 \\
(0.00148)\end{array}$ & $\begin{array}{c}0.0119^{*} \\
(0.00624)\end{array}$ \\
\hline Inflation $_{j, t}$ & $\begin{array}{c}-0.00649^{* * *} \\
(0.00226)\end{array}$ & $\begin{array}{l}0.000198 \\
(0.00622)\end{array}$ & $\begin{array}{l}-0.0125^{*} \\
(0.00725)\end{array}$ & $\begin{array}{l}0.0467^{*} \\
(0.0263)\end{array}$ \\
\hline 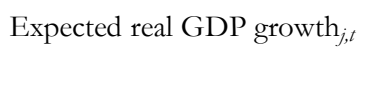 & $\begin{array}{l}-0.00133 \\
(0.00206)\end{array}$ & $\begin{array}{l}-0.00591 \\
(0.00537)\end{array}$ & $\begin{array}{c}-0.0357^{* * *} \\
(0.00580)\end{array}$ & $\begin{array}{c}0.123 * * * \\
(0.0281)\end{array}$ \\
\hline Expected inflation $_{j, t}$ & $\begin{array}{l}-0.00586^{*} \\
(0.00350)\end{array}$ & $\begin{array}{c}-0.0266^{* *} \\
(0.0103)\end{array}$ & $\begin{array}{l}-0.0306^{*} \\
(0.0161)\end{array}$ & $\begin{array}{l}-0.0370 \\
(0.0531)\end{array}$ \\
\hline Expected default frequency $_{j, t}$ & $\begin{array}{l}-0.000591 \\
(0.00282)\end{array}$ & $\begin{array}{l}-0.00775 \\
(0.00939)\end{array}$ & $\begin{array}{l}0.0273^{* * *} \\
(0.00934)\end{array}$ & $\begin{array}{l}-0.0691 * \\
(0.0399)\end{array}$ \\
\hline NPL ratio ${ }_{i, j, t-1}$ & $\begin{array}{l}-0.00213^{* *} \\
(0.000806)\end{array}$ & $\begin{array}{l}0.00201 \\
(0.00220)\end{array}$ & $\begin{array}{c}0.00652^{* * *} \\
(0.00180)\end{array}$ & $\begin{array}{c}-0.0471 * * * \\
(0.0101)\end{array}$ \\
\hline Regulatory capital ratio $i_{i j, t-1}$ & $\begin{array}{l}-0.000902 \\
(0.00105)\end{array}$ & $\begin{array}{c}-0.00432 * * \\
(0.00212)\end{array}$ & $\begin{array}{l}-0.000431 \\
(0.00238)\end{array}$ & $\begin{array}{c}-0.0135 \\
(0.00872)\end{array}$ \\
\hline Cost-to-income ratio $i_{i, j, t-1}$ & $\begin{array}{c}-0.000312^{* *} \\
(0.000131)\end{array}$ & $\begin{array}{c}0.000468 \\
(0.000359)\end{array}$ & $\begin{array}{c}-0.000735^{* *} \\
(0.000285)\end{array}$ & $\begin{array}{l}-0.00332 \\
(0.00243)\end{array}$ \\
\hline Liquid asset ratio ${ }_{i j, t-1}$ & $\begin{array}{c}-0.00112 * * * \\
(0.000419)\end{array}$ & $\begin{array}{l}-0.00210^{* *} \\
(0.000966)\end{array}$ & $\begin{array}{c}-0.00242^{* *} \\
(0.00110)\end{array}$ & $\begin{array}{l}-0.00609 \\
(0.00543)\end{array}$ \\
\hline Maturity gap $\mathrm{p}_{i, j, t-1}$ & $\begin{array}{c}0.000676 * * \\
(0.000257)\end{array}$ & $\begin{array}{l}0.000840^{*} \\
(0.000474)\end{array}$ & $\begin{array}{c}0.000300 \\
(0.000304)\end{array}$ & $\begin{array}{c}0.00372 * * \\
(0.00143)\end{array}$ \\
\hline $\begin{array}{l}\text { Bank FE } \\
\text { Number of observations } \\
\text { R2 }\end{array}$ & $\begin{array}{c}\text { YES } \\
750 \\
0.955 \\
\end{array}$ & \begin{tabular}{|l} 
YES \\
744 \\
0.673 \\
\end{tabular} & $\begin{array}{c}\text { YES } \\
751 \\
0.627 \\
\end{array}$ & \begin{tabular}{|l} 
YES \\
845 \\
0.467 \\
\end{tabular} \\
\hline
\end{tabular}

Note: Dependent variables: NII $=$ net interest income as a percent of assets; NNI $=$ non-interest income as a percent of assets; $\mathrm{PROV}=$ provisions; $\mathrm{ROA}=$ return on assets. $Y_{t-1}$ denotes the lagged dependent variable.. Data are at quarterly frequency covering an unbalanced sample of 234 banks for the period Q12007 - Q4 2016. Standard errors clustered at bank level in parentheses: * p<.1, ** $\mathrm{p}<.05, * * * \mathrm{p}<.01$ 


\section{Appendix 3 - Non-standard measures}

Since the onset of the financial crisis, the European Central Bank has reacted by announcing and implementing a series of non-standard monetary policy measures. The table below presents the main announcements used in the analysis.

Table A.3.1 Non-standard monetary policies

\begin{tabular}{|c|c|c|}
\hline Date & Type & Announcement \\
\hline $26 / 07 / 2012$ & OMT & "Whatever it takes" speech by ECB President Mario Draghi in London \\
\hline $02 / 08 / 2012$ & OMT & Outright Monetary Transactions programme (OMT) \\
\hline $06 / 09 / 2012$ & OMT & Technical features of OMT \\
\hline $08 / 05 / 2014$ & TLTRO & $\begin{array}{l}\text { President of the ECB explicitly stated during the press conference that the } \\
\text { Governing Council was willing to act in the following month }\end{array}$ \\
\hline 05/06/2014 & TLTRO, NIR & $\begin{array}{l}\text { Targeted longer-term refinancing operations (TLTROs); DFR=-10bps } \\
\text { (10bps cut) }\end{array}$ \\
\hline $03 / 07 / 2014$ & TLTRO & Announcement of TLTROs \\
\hline $04 / 09 / 2014$ & ABSPP , CBPP3, NIR, APP & Announcement of ABSPP, CBPP3; DFR=-20bps (10bps cut) \\
\hline $22 / 01 / 2015$ & APP & $\begin{array}{l}\text { Announcement of APP1 (combined monthly purchases of } € 60 \text { billion } \\
\text { (CBPP, ABSPP, PSPP). Intended purchases: } € 1.14 \text { trillion (The Governing } \\
\text { Council also decided to modify the interest rate applicable to future } \\
\text { TLTRO eliminating the 10bps spread over the MRO) }\end{array}$ \\
\hline 05/03/2015 & $\mathrm{APP}$ & APP details \\
\hline 09/03/2015 & APP & APP first operation \\
\hline $03 / 12 / 2015$ & APP, NIR & $\begin{array}{l}\text { APP extended until March 2017, reinvestment of principal payments, } \\
\text { inclusion of debt instruments issued by regional and local governments; } \\
\text { DFR=-30bps (10bps cut, MRO and MLF unchanged) }\end{array}$ \\
\hline $04 / 12 / 2015$ & APP speech & $\begin{array}{l}\text { Speech by ECB President Mario Draghi, Economic Club of New York, } 4 \\
\text { December } 2015\end{array}$ \\
\hline $10 / 03 / 2016$ & APP, TLTRO, CSPP, NIR & $\begin{array}{l}\text { APP (monthly purchases expanded to } € 80 \text { billion), TLTRO2, CBPSPP } \\
\text { investment-grade euro-denominated bonds issued by non-bank } \\
\text { corporations); DFR=-40bps (10bps cut) }\end{array}$ \\
\hline $08 / 12 / 2016$ & APP & APP extended until December 2017; €60bn, DFR floor constraint dropped \\
\hline
\end{tabular}

